\title{
Pontius Pilate as a Late Antiquity ANd EARly Medieval Judge - ICONOGRAPHIC REPRESENTATIONS
}

The image of a judge in Late Antiquity is shrouded in mystery as visual artefacts depicting court proceedings are scarce. We do not know what the uniforms or accessories of the officials looked like or of any attributes used, nor are we familiar with the courtroom interiors.

Early Christian sarcophagi and miniatures adorning early manuscripts help in researching this topic. Illustrations of the trial of Jesus found there fully represent jurisprudence of the $4^{\text {th }}$ and $5^{\text {th }}$ century. Western artists had no knowledge of the hearing held at the beginning of the first century in Jerusalem, in a Roman province, hence they recreated what they knew from experience. The pictures presenting the trial of Jesus are probably the most important iconographic evidence of court proceedings in which a judge and an accused stand facing each other. In this paper, I will try to outline the image of a late ancient judge using the example of Pilate, present in the art of the first centuries of Christianity.

There have been many papers written recently on the trial of Jesus in which Pilate had a significant role. Most of these research works focus on legal and historic aspects of this event. Researchers such as Paulina Święcicka, Maciej Jońca, Marek Kuryłowicz, Marek Sobczyk and John Dominic Crossan scrutinise written sources and present thorough interpretations. ${ }^{1}$ There are attempts made to create psychological profiles of Saviour's ex-

* Ph.D., Assistant Professor, the Cardinal Stefan Wyszyński University in Warsaw; e-mail: r.rupiewicz@uksw.edu.pl, ORCID ID: https://orcid.org/0000-0002-8863-6542.

1 M. Sobczyk, Proces Jezusa oczami historyka i prawnika, Studia Iuridica Toruniensia 2013, vol. 12, pp. 221-253; P. Święcicka, Proces Jezusa w świetle prawa rzymskiego. Studium prawno-historyczne, Warszawa 2012; M. Jońca, Czyste ręce prefekta Judei, Palestra 2016, vol. 61, no. 3, pp. 146-150; idem, Głośne rzymskie procesy karne, Wrocław 2009; M. Kuryłowicz, Prawa antyczne. 
ecutioners and judges. ${ }^{2}$ It is not my objective to discuss the vast literature on the trial of Jesus, with new works being published almost each year and trying to answer how it happened and who was eventually responsible for the verdict - the Sanhedrin or Pilate? I would like to focus on the representation of Pilate, the embodiment of the imperial judicial power depicted in the artefacts dating from the first centuries of our era. Hence, my source materials are focused, not on the Gospels or works of literature from that period but on the most representative works of art from that time.

At this point it seems appropriate to mention Column P. Hourihane, an outstanding art historian, the author of the most important research work on Pilate's iconography. ${ }^{3}$ He concentrates, however, on topics related to anti-Judaism. The ways Pilate was depicted is discussed in my book on the Iudicium sanguinarium motif, in which the reader can find detailed bibliography. ${ }^{4}$

Until the third century, presentations of the Passion are rare. Since the beginning of the $4^{\text {th }}$ century scenes of the trial of Jesus most frequently have depicted Pilate on a throne, sitting in majestic pose and holding the attributes of the governor's office. A throne or a sella curulis is situated on a podium and Pilate's crossed feet are on a footrest. The judge wears a Roman cloth of the toga picta type, and his head is decorated with a laurel wreath or a tiara. Christian art imitates pagan representations of rulers, governors and high-ranking Roman officials. ${ }^{5}$ In particular, the arrangement of the legs links back to pre-Christian imperial iconography. ${ }^{6}$ There are objects indicating the legal and administrative proceedings relating to announcement of death sentence. Pilate is an embodiment of law. Jesus is not tied up or suffering, and his clothes are noble. The artists clearly point to the high priests and Herod as being responsible for Jesus's death, whereas Pilate's accountability is diminished.

An interesting artefact is the sarcophagus of Junius Bassus, dated back to year 359 and housed in the Museo Storico del Tesoro della Basilica di

Wyktady z historii najstarszych praw świata, Lublin 2006; J.D. Crossan, Who Killed Jesus? Exposing the Roots of Anti-Semitism in the Gospel Story of the Death of Jesus, San Francisco 1995.

2 P. Lisicki, Kto zabił Jezusa? Prawda i interpretacje, Kraków 2013.

3 C. Hourihane, Pontius Pilate, Anti-Semitism, and the Passion in Medieval Art, Princeton 2009.

4 R. Rupiewicz, Sąd nad Jezusem. Studium ikonografii oraz źródet od chrześcijańskiego antyku do nowożytności, Warszawa 2018. This article is a continuation of research presented in the book.

5 C. Hourihane, Pontius Pilate, Anti-Semitism..., p. 59.

6 Ibidem, p. 61. 
San Pietro. Two compartments in the right upper corner depict Jesus before Pilate $^{7}$ (ill. 1, 2). In one of them, the Saviour is presented as a beautiful young man without facial hair, wearing a Roman tunic and holding a law scroll (ill. 1). Next to him there are two Roman soldiers looking up to him with respect and faith. In the second compartment Pilate sits on a curule seat (ill. 2). His head, supported by the palm of his hand, as if in a philosophical pose, is decorated with a laurel wreath. His face is absorbed in thought and his legs are crossed. The most important attributes - a bowl standing on a pedestal and a pitcher held by a servant - are exposed in the middle section of the compartment. It is also worth noting the juxtaposition of these scenes with their Old Testament counterparts carved on the opposite side of the relief in the bottom row. Pilate washing his hands completes the scene of the original sin. Job's ordeal is, in turn, a prelude to the arrest of Jesus, which is foretold by Daniel in the lions' den. Legal motifs are also shown in the scenes of the arrests of Saint Paul and Saint Peter, which, apart from the scenes from the Old Testament, constitute an analogy to the trial of Jesus. ${ }^{8}$

We can find a picture of a Late Antiquity judge in the Brescia Casket. ${ }^{9}$ The reliquary, made of ivory and dating back to 390, is located in Monastero di Santa Giulia (ill.3). The narrative was developed based on the typology of biblical events of which the trial of Susanna and the trial of Jesus constitute a subject of our interest. These scenes have been depicted together since the $4^{\text {th }}$ to the $17^{\text {th }}$ century,,$^{10}$ and their sources should be searched for in the catacomb paintings and the writings of Jerome, Augustine and Ambrose. Especially Ambrose stressed that the silence of Susanna during an unfair trial bears resemblance to the silence of Jesus before his accusers. ${ }^{11}$ These scenes are present on numerous Early Christian sarcophagi. ${ }^{12}$

7 P. du Bourguet, Early Christian Art, transl. T. Burton, New York 1971, p. 166; B. Filarska, Poczatki sztuki chrześcijańskiej, Lublin 1986, pp. 165-166.

8 Cf. J. Spier, Picturing the Bible. The Earliest Christian Art, New Haven-London 2008, p. 14.

9 The object housed in the Museo di Santa Giulia, Brescia. See: C. Hourihane, Pontius Pilate, Anti-Semitism..., pp. 53-54.

10 C. Brown Tkacz, Susanna as a Type of Christ, Studies in Iconography 1999, vol. 20, p. 101.

11 Ibidem, p. 103.

12 For example: three sarcophagi located in the Musée Départemental Arles Antique; among them a famous sarcophagus of two brothers, on which Susanna in the garden was juxtaposed with the trial of Jesus, presented symmetrically on the other end of the front relief. The iconography of the Arles sarcophagi had become a type commonly copied in 


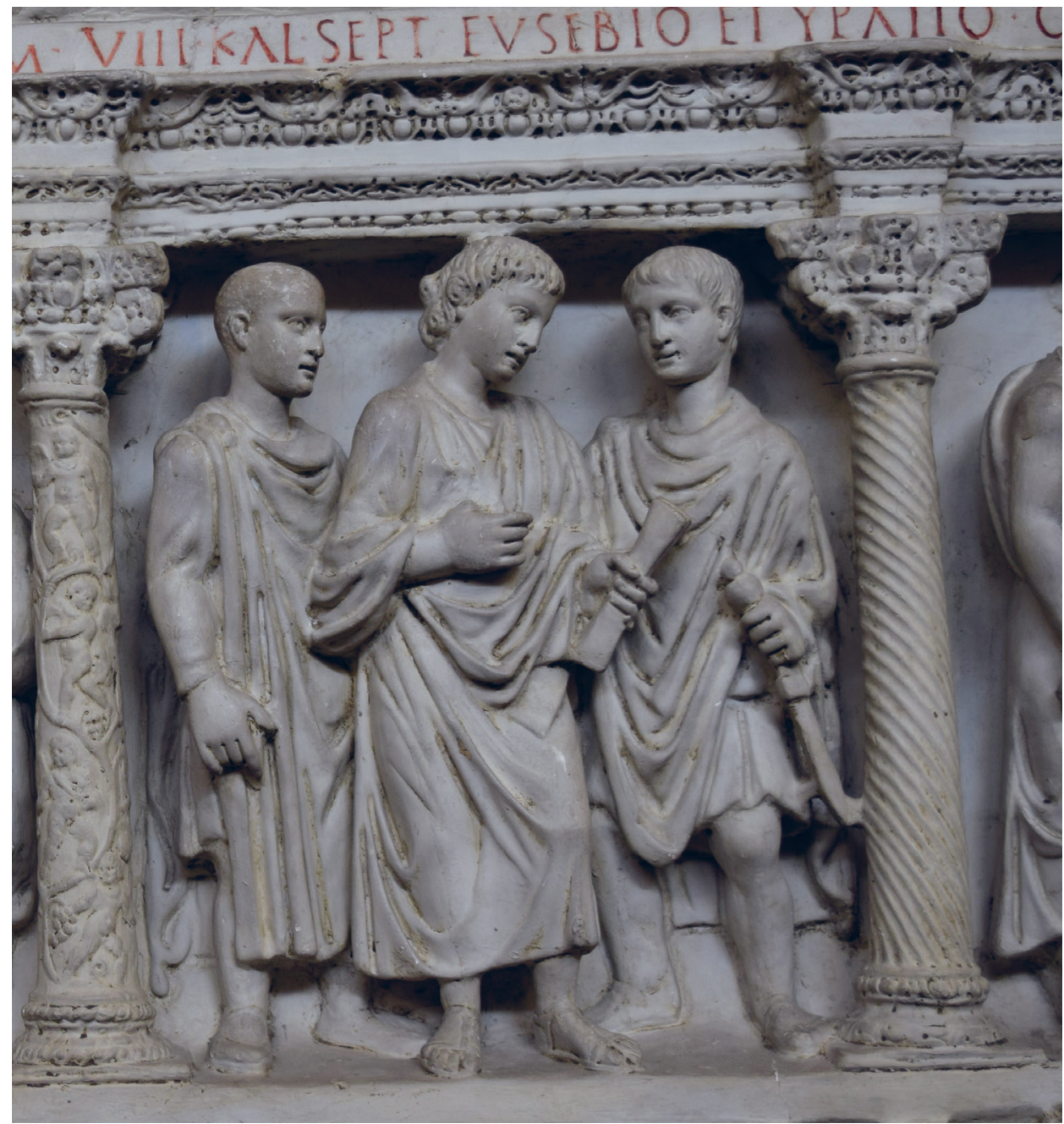

Ill. 1. Jesus. The Sarcophagus of Junius Bassus - detail, marble, A.D. 359, Museo Storico del Tesoro della Basilica di San Pietro (photo Joanna Barańska)

Furthermore, on the lid of the casket the stages of the trial of Jesus are presented in two rows. The narrative starts in the upper left corner, with a representation of Jesus in the olive garden, then his arrest and the denial of Peter. In the relief in the bottom row, the central figure is Pilate sitting on a throne placed on a podium. He is surrounded by four high rank

typology. Cf. A. Coburn Soper, The Latin Style on Christian Sarcophagi of the Fourth Century, The Art Bulletin 1937, vol. 19, no. 2, p. 160. 


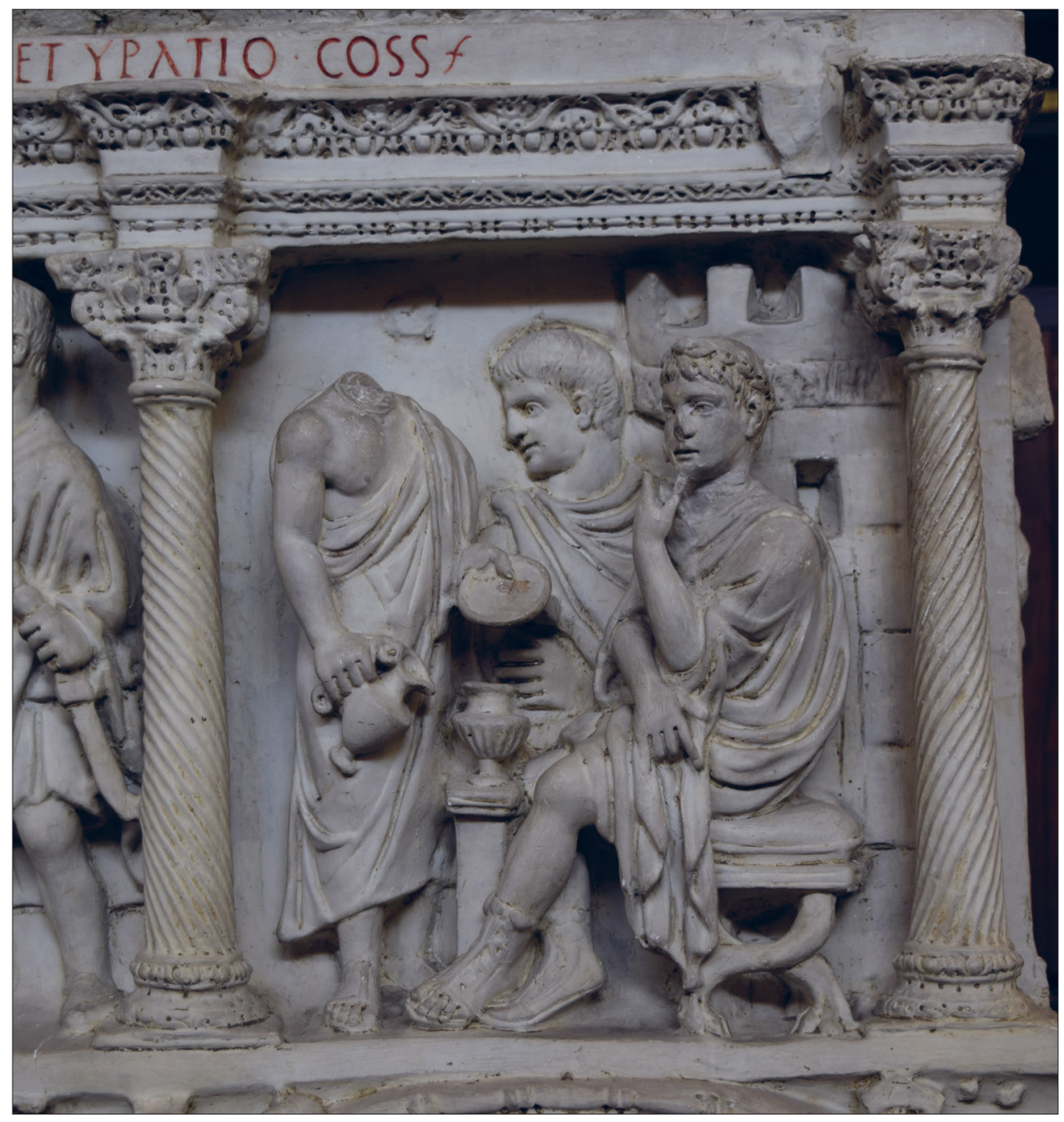

Ill. 2. Pilate. The Sarcophagus of Junius Bassus - detail, marble, A.D. 359, Museo Storico del Tesoro della Basilica di San Pietro (photo Joanna Barańska)

officials. To his right stands a servant washing Pilate's hands. On the left, there is Jesus escorted by two Roman soldiers. Pilate looks in the opposite direction, directly on Caiaphas and Annas. High priests, carved in the left corner, sit on curule chairs and point to Jesus standing before them among temple guards. Their legs are crossed. Jesus looks at them intensely, as does Pilate. The hairless face of the Saviour is calm. He extends his right hand to the priests, as if reprimanding them for their wrongdoing. In this section, the figure of Jesus appears twice. The sentry guards wearing short 


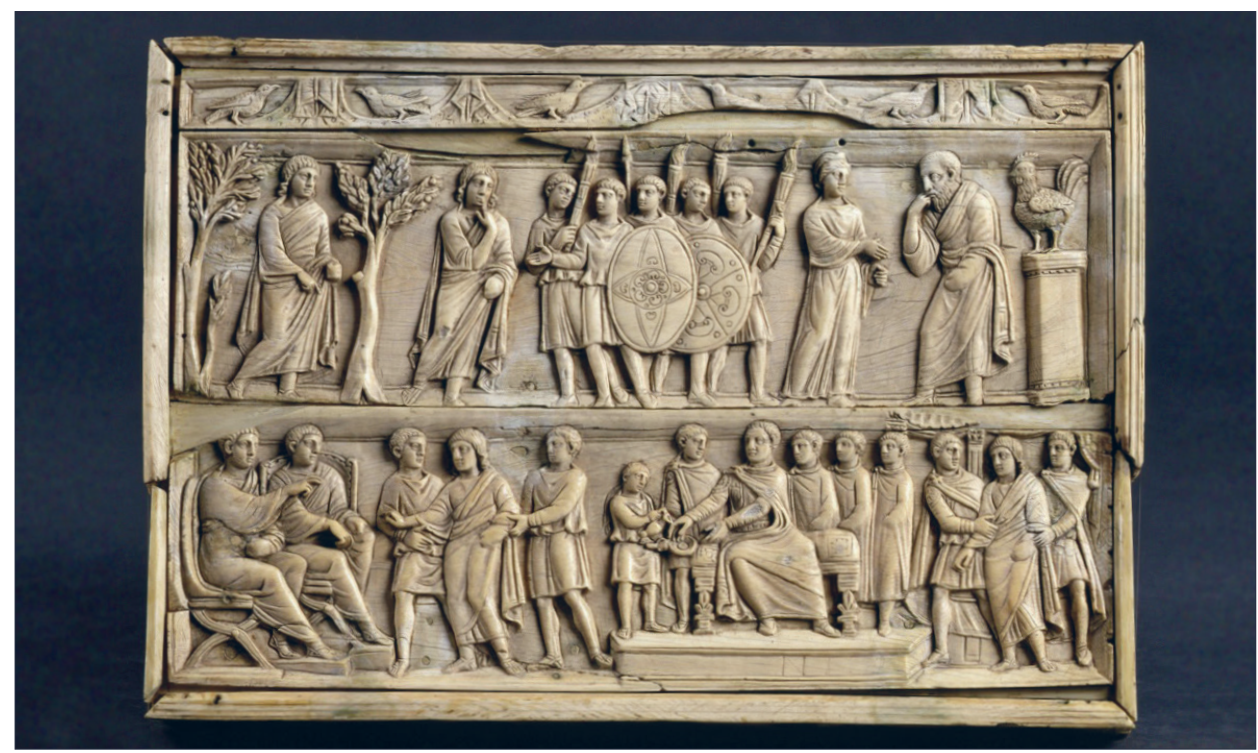

Ill. 3. The Brescia Cascet, end of the $4^{\text {th }}$ century, Museo di Santa Giulia, Brescia

tunics are worth noticing. Both of them look at Jesus with reverence. They touch him softly and with respect. The situation is repeated in the left-hand side of the simultaneous narrative. Jesus stands behind Pilate, flanked by the two Roman soldiers who closely watch his face. Their looks are faithful and convinced of his innocence. The message conveyed in this scene is clear - the high priests bear the responsibility for the death sentence. It is supported by the manner in which Pilate is shown, the prominent act of washing hands and the telling look in the direction of the Jews. The similar manner of depicting Pilate has continued to be shown for a long time, as it is demonstrated by the mosaic from San Apollinare Nouvo in Ravenna that dates back to the beginning of the $6^{\text {th }}$ century (ill. 4).

The bottom row of the front panel of the Brescia Casket shows Susanna in simultaneous scenes (ill. 5). On the left, she is presented in the commendatio animae style: in a pose of an orant woman wearing a white tunic, with arms lifted. Susanna is between two trees, behind which she is being watched by two old men. In the next scene Susanna is led by the men to stand before Daniel, the judge. These scenes have counterparts in the pictures of Jesus in the olive garden praying between two trees and then being taken by the Jews to Pilate. ${ }^{13}$

13 C. Brown Tkacz, Susanna as a Type..., pp. 106, 108. 


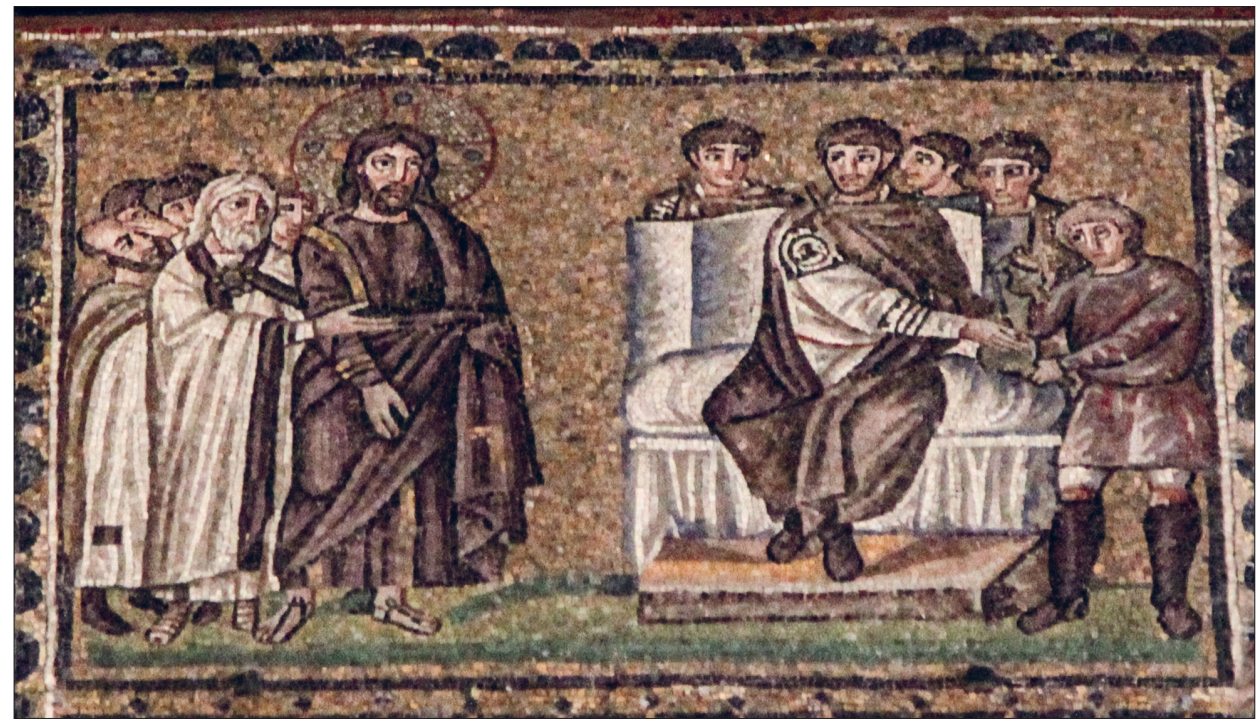

Ill. 4. Christ before Pilate, mosaic, $6^{\text {th }}$ century, Sant' Apollinare Nouvo Ravenna (photo Paweł Kęska)

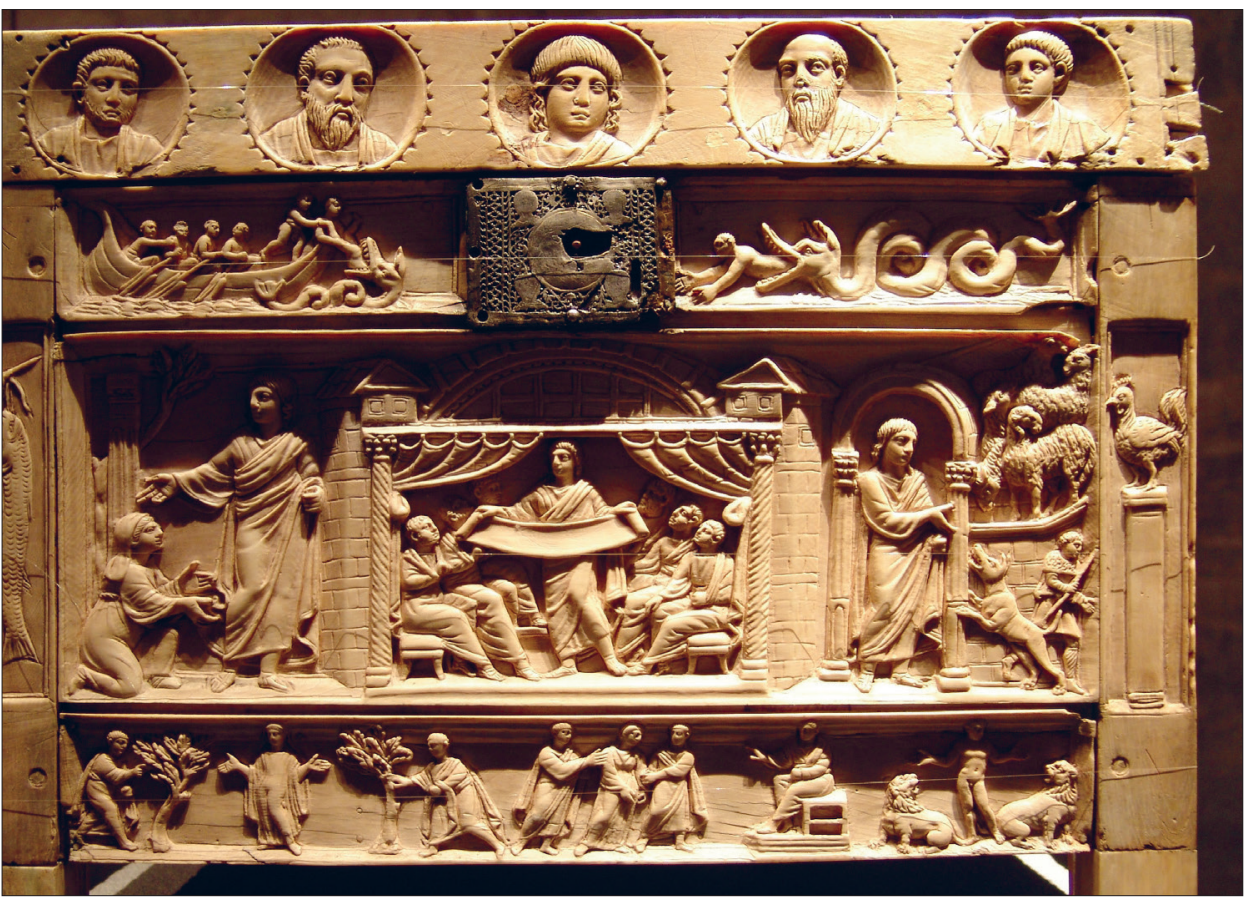

Ill. 5. The Brescia Cascet - detail, end of the $4^{\text {th }}$ century, Museo di Santa Giulia, Brescia (photo author) 
Another prefiguration of the accused Jesus can be drawn from the description of prophet Daniel judged by Nebuchadnezzar (Dn 2,24-25). ${ }^{14}$ On the Brescia Casket this topic is symbolically evoked by depicting the prophet amongst lions. He stands in the orant pose, also in the commendatio animae style; this depiction refers to the motif of Susanna through formal analogy. Trials of Susanna and Christ are also juxtaposed in the medieval religious writings. This topic appears in the writings of Venerable Bede, Alcuin, Haimo of Auxerre, Abelard and Henry Suso, and has been discussed in detail by Catherine Brown Tkacz. ${ }^{15}$ The image of the prophet Daniel and Pilate is probably a revision of the trial scenes from the end of the $4^{\text {th }}$ century. It can be assumed that Pilate constitutes an image of a Late Antiquity official or emperor acting as a judge.

The Museo Pio Cristiano at the Vatican stores two sarcophagi dating back to the first half of the $4^{\text {th }}$ century which showcase the trial scenes without Jesus, Caiaphas or Annas being present. The relief of the first of them, known as the Sarcophagus of Two Brothers (ill. 6), presents Pilate deep in thought, with his head resting on the hand in a pose associated with philosophers. His face is turned away from the elders accompanying him and from a servant holding an ewer. He is alone, looking into the distance, beyond what is happening in individual sequences of the Passion. ${ }^{16}$ What is Pilate thinking of? Maybe he is pondering on the question he asked during the trial: what is truth? (Jn. 18,38). A symbolic presence of the Saviour is hinted by a preceding scene showing the sacrifice of Isaac. ${ }^{17}$ Isaac is a type of representation of Jesus and a portent of his sacrifice.

The second sarcophagus, from the catacombs of Domitilla, presents the trial of Jesus in a similar manner. It also depicts scenes from the Passion (ill. 7, 8).$^{18}$ Next to Pilate there is a servant holding a pitcher and a Roman official. The governor turns his head away from the adjoining compartment in which there is Jesus escorted by a soldier. He does not look at his servants either. Pilate's coat and a tiara on his head indicate the imperial

14 Such pre-figuration is mentioned by S. Kobielus, however there is no example in the art provided. Cf. S. Kobielus, Concordia Novi et Veteris Testamenti. Zapowiedzi dzieta odkupienia i jego spetnienie w teologii i sztuce średniowiecza, Poznań 2013, p. 134.

15 C. Brown Tkacz, Susanna as a Type..., pp. 117-120.

16 Cf. J. Spier, Picturing the Bible..., pp. 219-220.

17 See C. Hourihane, Pontius Pilate, Anti-Semitism..., p. 56.

18 Sarcophagus with the Passion scenes, c. A.D. 350, Musei Vaticani, inventory no. 31525. Bibliography in: J. Spier, Picturing the Bible..., pp. 219-220. 


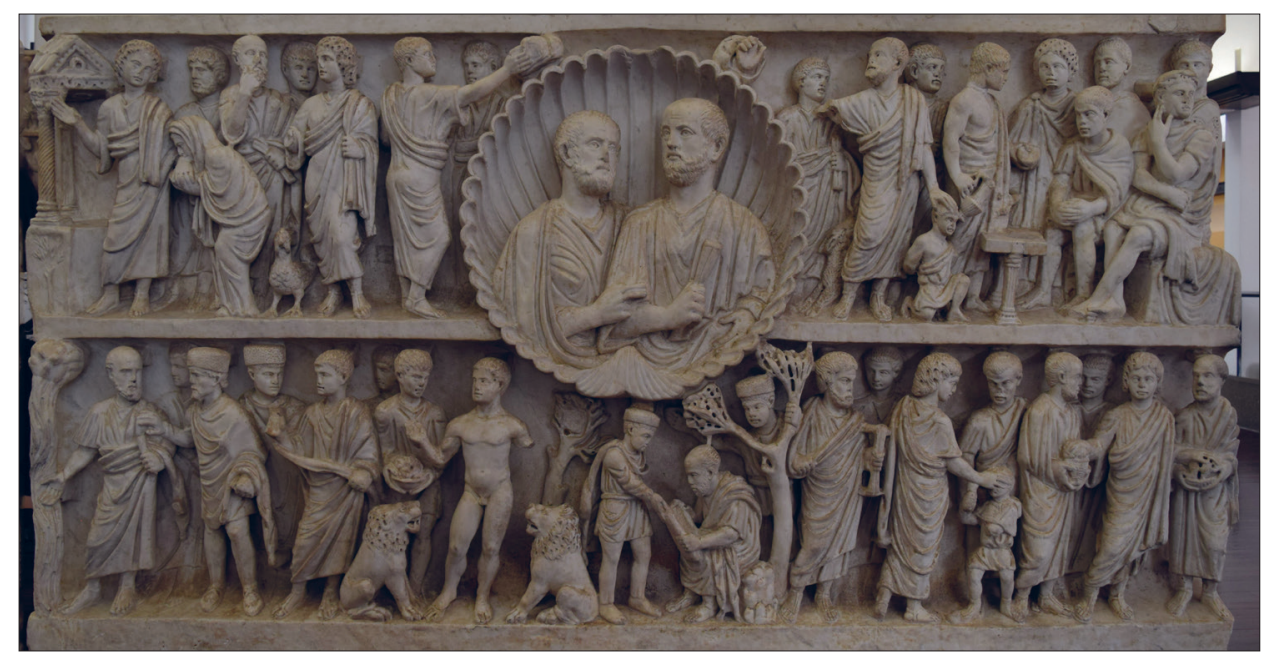

Ill. 6. Sarcophagus of the "Two Brothers", marble, c. A.D. 325-350, Museo Pio Cristiano, Rome (photo Joanna Barańska)

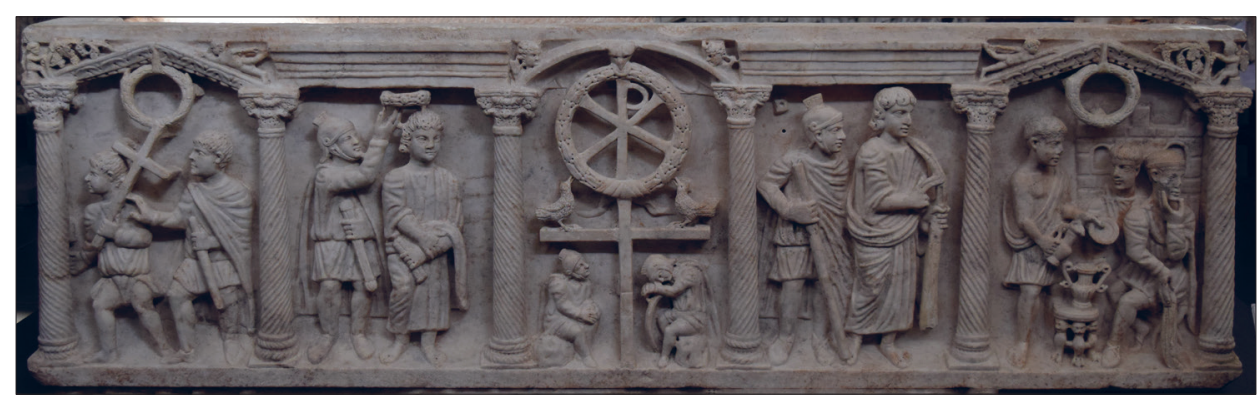

Ill. 7. Sarcophagus with scenes from the Passion of Christ, c. A.D. 350, Musei Vaticani, inv. no. 31525 (photo Joanna Barańska)

rank of the governor. Above the figures hangs a laurel wreath fixed to a tympanum. A similar wreath is found symmetrically in a compartment on the opposite side of the sarcophagus, hanging above the head of Simon of Cyrene helping Jesus to carry the cross. ${ }^{19}$

The figure of Pilate washing his hands is a crucial element in depicting the trial of Jesus in early representations of the topic. The gesture of the governor is significant in the interpretation of works of art. A pitcher

19 Pilate turning his head away from Jesus is also depicted on a Roman sarcophagus from the last quarter of the $4^{\text {th }}$ century, currently stored in the museum in Arles. 


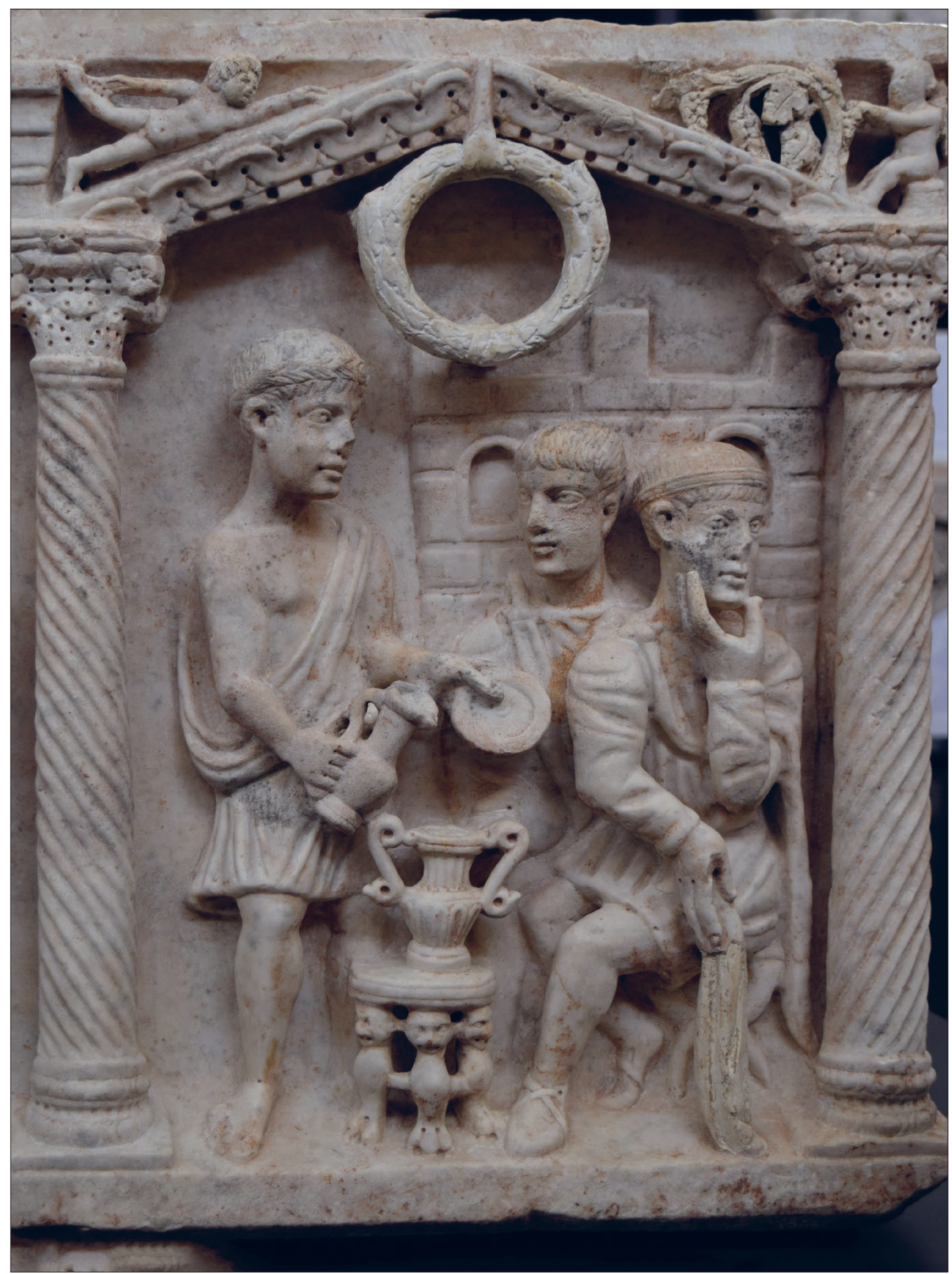

Ill. 8. Sarcophagus with scenes from the Passion of Christ - detail, c. A.D. 350, Musei Vaticani, inv. no. 31525, detail (photo Joanna Barańska) 
and a basin are the most important attributes of Pilate, even though it is only Matthew the Apostle who mentions the act of washing hands (Mt. 27,24). This gesture is prominent in the majority of early representations of this motif found on objects made until the $5^{\text {th }}$ century. It was introduced to Christian liturgy, something we can conclude based on source texts and artwork, such as a miniature in the Stuttgart Psalter. ${ }^{20}$ This act signified innocence and was a part of Jewish, and not Roman, tradition. ${ }^{21}$ Ablution of body or its parts symbolised purification from sins, absolution and baptism. That was the meaning of washing the disciples' feet during the last supper described by John the Apostle (Jn. 4,1-2). The motif of washing hands has an evangelical element, however all other parts of the composition - such as the laurel wreath - refer to the contemporary legal system.

In the early Christian period, scenes of Pilate's hand-washing and the washing of the Apostles' feet were often paired. A Roman marble sarcophagus from the end of the $4^{\text {th }}$ century (ill. 9) stored in Arles can serve as an example. ${ }^{22}$ The central part of the decoration in relief presents a traditio Legis scene. Jesus stands on a rock from which paradise rivers flow. Next to him there are four Apostles and the scenes in two external arcades depict acts of purification. On the right there is Pilate sitting on a pedestal surrounded by courtiers who are about to wash his hands. The governor points his hand to Jesus among the Apostles but turns his head in the opposite direction. His thoughtful face shows inner dilemma. On the ground there is a decorated bowl to which a servant gestures towards. On the left side of the relief there is Peter sitting on a pedestal. The arrangement of his legs and the pose in which he is depicted are almost identical to Pilate's. With his left hand Peter points to Jesus, but he looks directly at the viewer towards whom he extends his other hand in protest against what Jesus wants to do. Peter is torn and perplexed like Pilate. Jesus points to a vessel standing on the ground. It is significant that the figure of the Saviour is juxtaposed with a servant washing the governor's hands. Through this symbolic parallel the servant is elevated to the rank of a priest celebrating the sacrament.

20 The Stuttgart Psalter, Landesbibliothek, inventory no. 23, fol. 66.

21 M. Jońca, Czyste ręce..., p. 149.

${ }^{22}$ Musée Departemental Arles Antique, FAN.92.00.2487. A detailed bibliography related to the sarcophagus and its iconographic analysis can be found in: J. Spier, Picturing the Bible..., pp. 242-243. 


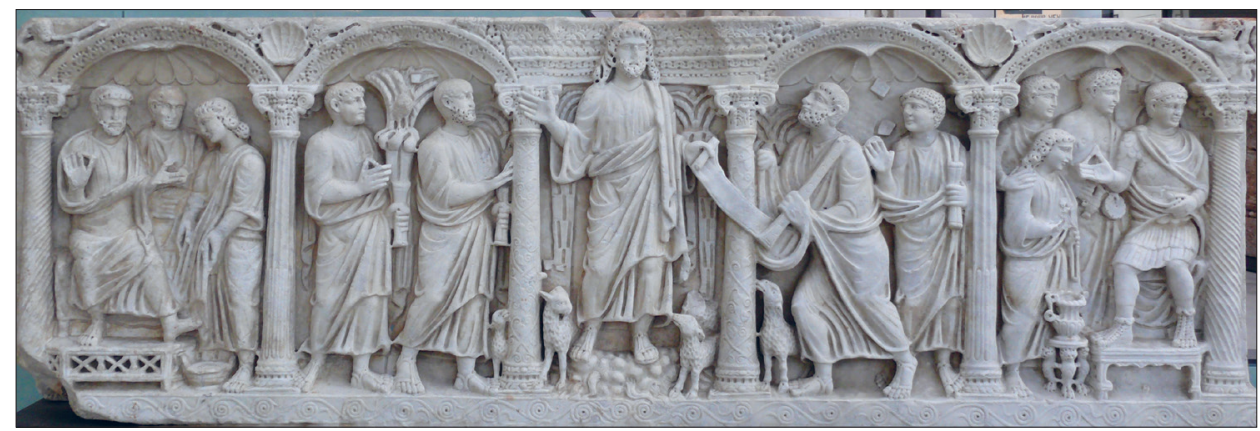

Ill. 9. Sarcophagus depicting the law delivered to Saint Peter, end of the $4^{\text {th }}$ century, Musée Departemental Arles Antique, FAN.92.00.2487 (photo author)

Similar scenes can be found on other early Christian sarcophagi $i^{23}$ and on numerous medieval objects. The act of washing hands was displayed so much due to the conviction over the innocence of the Roman governor. According to Justin Martyr, Pilate believed that water rinses off his sin and enables spiritual rebirth. ${ }^{24}$ Some Christian writers concluded that Pilate had converted to Christianity. Colum Hourihane has made an attempt to collect sources confirming this thesis. It is difficult however to agree with him that the writings of Origen and Eusebius of Caesarea should be considered among them. The researcher quotes fragments from these texts but - in my opinion - it is too far-fetched. ${ }^{25}$ It is certain that Tertullian recognised Pilate as Christian. He thought that the gesture of washing hands represents turning to Christ and is a prelude to baptism and conversion. ${ }^{26}$ He wrote in Apologeticus: "All these things Pilate did to Christ; and now in fact a Christian in his own convictions, he sent word of Him to the reigning Caesar who was at the time Tiberius." 27 According to Cyril of Jerusalem the gesture of washing hands was a symbolic sign of purifying sin. This motif also appeared in Saint Jerome's writings:

${ }^{23}$ Musei Vaticani, Museo Pio Cristiano, inventory no. 151.

24 Justin Martyr, Apology 1, 66, in: The Apologies of Justin Martyr, transl. A. Roberts, J. Donaldson, with brief notes and prefaces A. Cleveland Coxe, Greenwood 2012.

25 C. Hourihane, Pontius Pilate, Anti-Semitism..., p. 80.

26 Tertullian's sources collected by: ibidem, pp. 69-70.

27 T.P. Henderson, The Gospel of Peter and Early Christian Apologetics. Rewriting the Story of Jesus's Death, Burial and Resurrection, Tübingen 2011, p. 88. 
Pilate took water in accordance with the following prophecy: "I will wash my hands among the innocent" (Ps 26,6). Thus, in the washing of his hands, the works of the Gentiles are cleansed, and in some manner he estranges us from the impiety of the Jews who shouted: "Crucify him!". For he contested this and said: "I certainly wanted to set the innocent man free." 28

Saint Leo the Great, contrary to Tertullian, perceived the hand-washing act as a sign of weakness, powerlessness and fear of the governor. ${ }^{29}$ Venerable Bede wrote that more guilty than Pilate were those who forced him to pass the sentence and "who killed Christ with their venomous tongues shouting: 'Crucify, crucify him'." ${ }^{30}$ Paschasius Radbertus (d. 865) treated Pilate's washing of hands as a fulfilment of the prophecy: "I will wash my hands among the innocent" (Ps 26,6) $\cdot{ }^{31}$ Candidus of Fulda gives an interesting interpretation of Pilate's gesture:

Pilate washing hands signified people who through baptism purged themselves from the blood of the innocent. It was an ancient custom that if someone wanted to be seen innocent, he had to wash his hands before witnesses. That is why the Psalmist says: "I will wash my hands among the innocent." ${ }^{2}$

In medieval religious literature there is also an account of Anselm of Laon who wrote about forcing Pilate to pass the death sentence and calling Jesus innocent. ${ }^{33}$ In the writings of the Church Fathers, we can find a negative assessment of Pilate - an opinion which is in minority, though. John Chrysostom, commenting on the washing of hands, called Pilate a weak and soft man who did not resist the crowd and was as "corrupted" as the Jews. ${ }^{34}$

The sources provided above convey the "spirit of the age" and the general perception of Pilate as an innocent man who was aware of the resentment of the Jews. The iconography reflected that attitude. In $4^{\text {th }}$ century art,

28 Quoted in: S. Kobielus, Concordia Novi..., p. 135. English translation after: The Fathers of the Church. St. Jerome: Commentary on Matthew, ed. R.J. Deferrari, Th.P. Halton, transl. Th.P. Scheck, Washington D.C. 2008.

29 Cf. C. Hourihane, Pontius Pilate, Anti-Semitism..., p. 70.

30 S. Kobielus, Concordia Novi..., p. 135.

31 Ibidem.

32 Ibidem, pp. 135-136.

33 Ibidem, p. 136.

34 Jan Chryzostom Św., Homilie na Ewangelię wedtug św. Mateusza. Część druga: homilie 41-90, ed. A. Baron, transl. A. Baron, J. Krystyniacki, Kraków 2001, p. 493. 
sometimes two servants pour a lot of water over Pilate's hands. It seems to infer persons assisting with the sacrament of baptism.

A wooden door from the Basilica di Santa Sabina in Rome dating back to the beginning of the $5^{\text {th }}$ century (ill. 10) is decorated with a relief showing the governor washing his hands. Pilate sits on a sella curulis, with his legs crossed and looks directly at the viewer. On his left-hand side one can see Jesus walking away with the cross, surrounded by the Jews. This scene is paired with a scene on the right-hand side showing Moses crossing the Red Sea which symbolises baptism. ${ }^{35}$ It is a quite original comparison, once again presenting Pilate as a converted sinner.

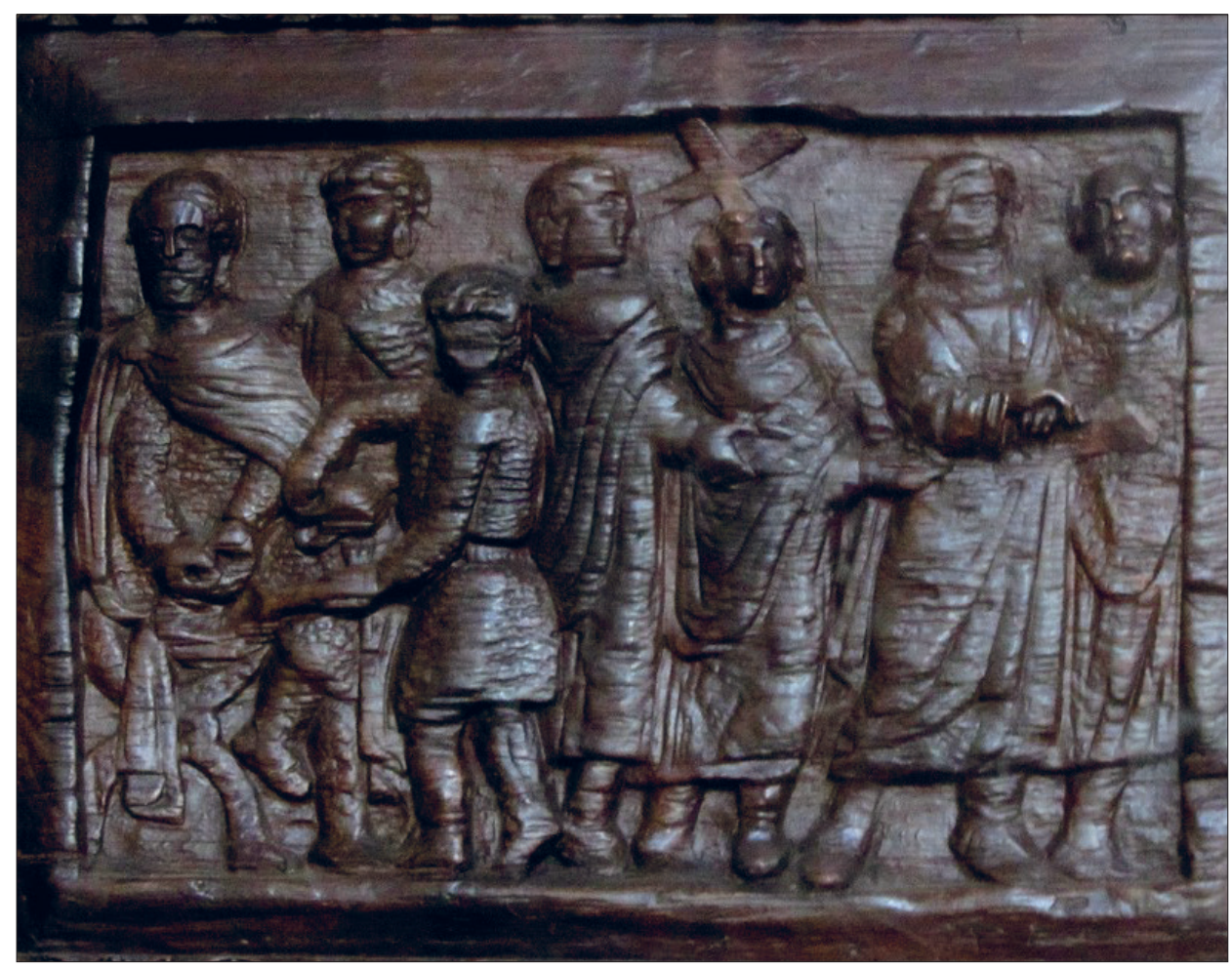

Ill. 10. The doors on the exterior of Santa Sabina - detail, the beginning of the $5^{\text {th }}$ century, Santa Sabina, Rome (photo author)

35 Cf. C. Hourihane, Pontius Pilate, Anti-Semitism..., pp. 65 and 74. 
The manner in which Pilate is depicted changed in the second quarter of the $5^{\text {th }}$ century. The governor still stands as a symbol of law, but his part in passing the sentence is no longer diminished. Occasionally we can find artworks in which he is shown as a concerned thinker, turning his head away from Jesus, the ewer and the bowl. One of the early examples of this change is a panel dated between the years $420-430$ (ill. 11). Pilate is seated on a raised throne, looking at Jesus who is being taken away by a soldier to the execution site. The panel originally decorated a casket stored in the Basilica of Saint John Lateran in Rome. Currently it is housed at the British Museum in London. ${ }^{36}$

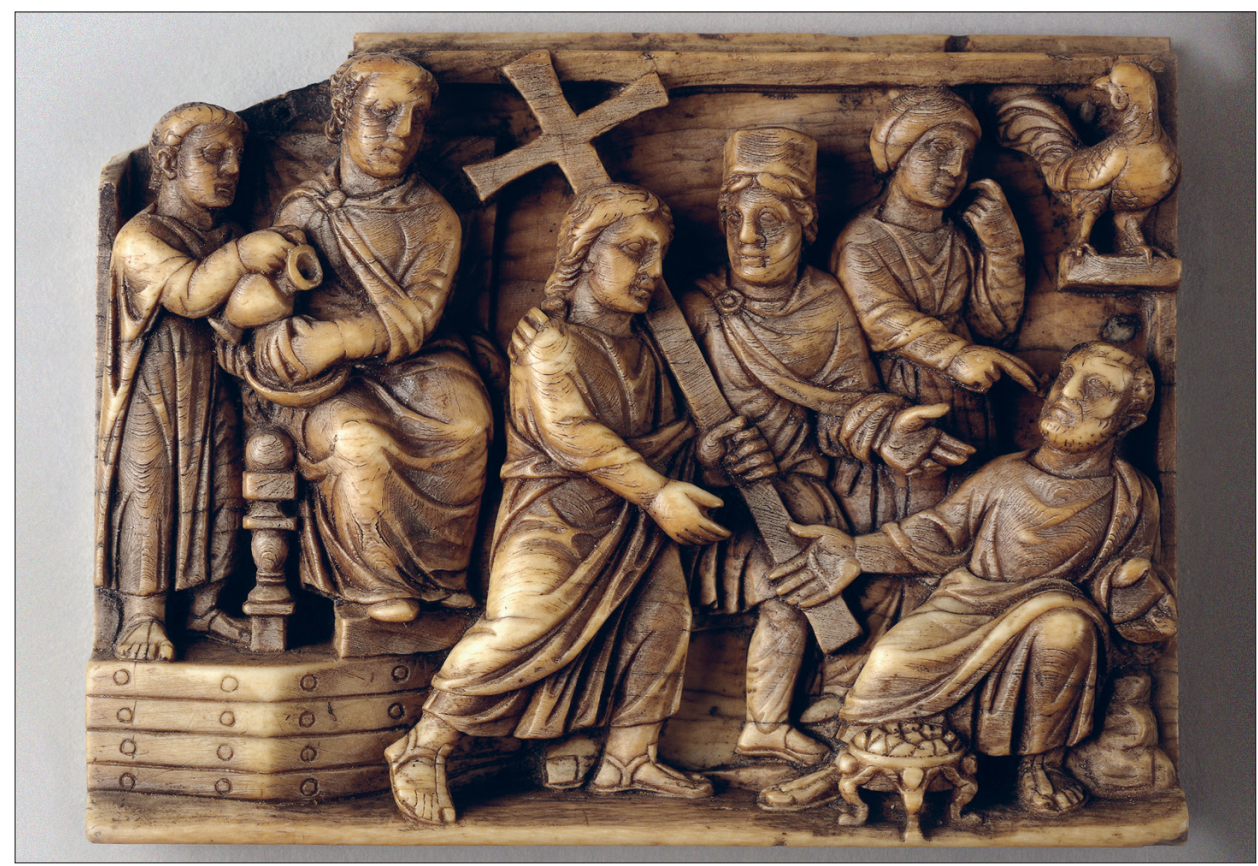

Ill. 11. Casket - one of four panels, ivory, carved in relief with the Judgement and Denial of St. Pete, c. 420-430,

The British Museum, inv. no. 1856,0623.4

36 One of the four panels of the ivory casket, c. 420-430, The British Museum, inventory no. 1856,0623.4. For the provenience of the panels cf. I. Foletti, The British Museum Casket with Scenes of the Passion: The Easter Liturgy and the Apse of St. John Lateran in Rome, in: The Fifth Century in Rome: Art, Liturgy, Patronage, ed. I. Foletti, M. Gianandrea, Rome 2017, pp. 139-159. Catalogue card and bibliography, https:/ / www.britishmuseum.org/collection/ object/H_1856-0623-4 [access: 14.07.2020]. 
In early illuminations and reliefs showing scenes of the trial of Jesus one can sometimes find a table whose purpose was to emphasise the distance between the judge and the Accused. The miniature decorating the margin of a leaf of the Rabbula Gospels (fol. 12v) from the year 586 follows this composition model ${ }^{37}$ (ill. 12). On the left margin there is Pilate sitting on the throne, on an ample green cushion. The governor wears a white tunic and a red mantle. He looks at Jesus, depicted on the right margin, and turns a lifted hand in his direction. The Accused stands alone, wearing antiquated clothes and sandals. His hair is short, reddish and curly. His head is surrounded by nimbus. His right hand is raised in greeting towards Pilate. ${ }^{38}$ Red hair is rare in the iconography of Jesus as the symbolism of this colour is equivocal. Usually this colour has negative connotations and is linked with, among others, Absalom and Judas. ${ }^{39}$ King David however, a positive character and a typical representational figure for Jesus, was also red-haired, so maybe the author of the miniature wanted to refer to one of the most important figures of the Old Testament who also foresaw the coming of Jesus.

On this miniature before Pilate's table stands a barefooted servant, wearing a short blue tunic exposing his legs. He holds barely visible attributes - an ewer and a basin which indicate that these are the final moments of the trial. Below Pilate's throne, on green grass stands the Saviour, forced to look up. It seems that such a composition had become the model one at the end of the $6^{\text {th }}$ century. The Rabbula Gospels are a valuable source of information on court trials. A table is located before the judge so we can assume that it was an important piece of furnishing in the room. Possibly it had a symbolic role relating to the signing of or pronouncing of verdicts.

When discussing early Christian representations of the trial of Jesus, it is impossible not to mention the miniature from the Rossano Gospels (fol. $8 \mathrm{r}$ and $8 v$ ), created in the $5^{\text {th }}$ or $6^{\text {th }}$ century, ${ }^{40}$ most probably in the eastern part

37 Cf. W.C. Loerke, The Miniatures of the Trial in the Rossano Gospel, The Art Bulletin 1961, vol. 43, no. 3, p. 176.

38 Almost identical depiction of Christ can be found in the Resurrection scene (The Rabbula Gospels, fol. 13, Biblioteca Laurenziana). There his hand is also raised in a greeting gesture, this time meant for women.

39 S. Kobielus, Ikonografia zdrady i śmierci Judasza. Starożytność chrześcijańska i średniowiecze, Ząbki 2005, pp. 20 and 57.

40 Dating of the manuscript is only possible based on the stylistics of miniatures and typography. Cf. G. Cavallo, Codex Purpureus Rossanensis, Roma 1992, p. 68. The researcher showed 


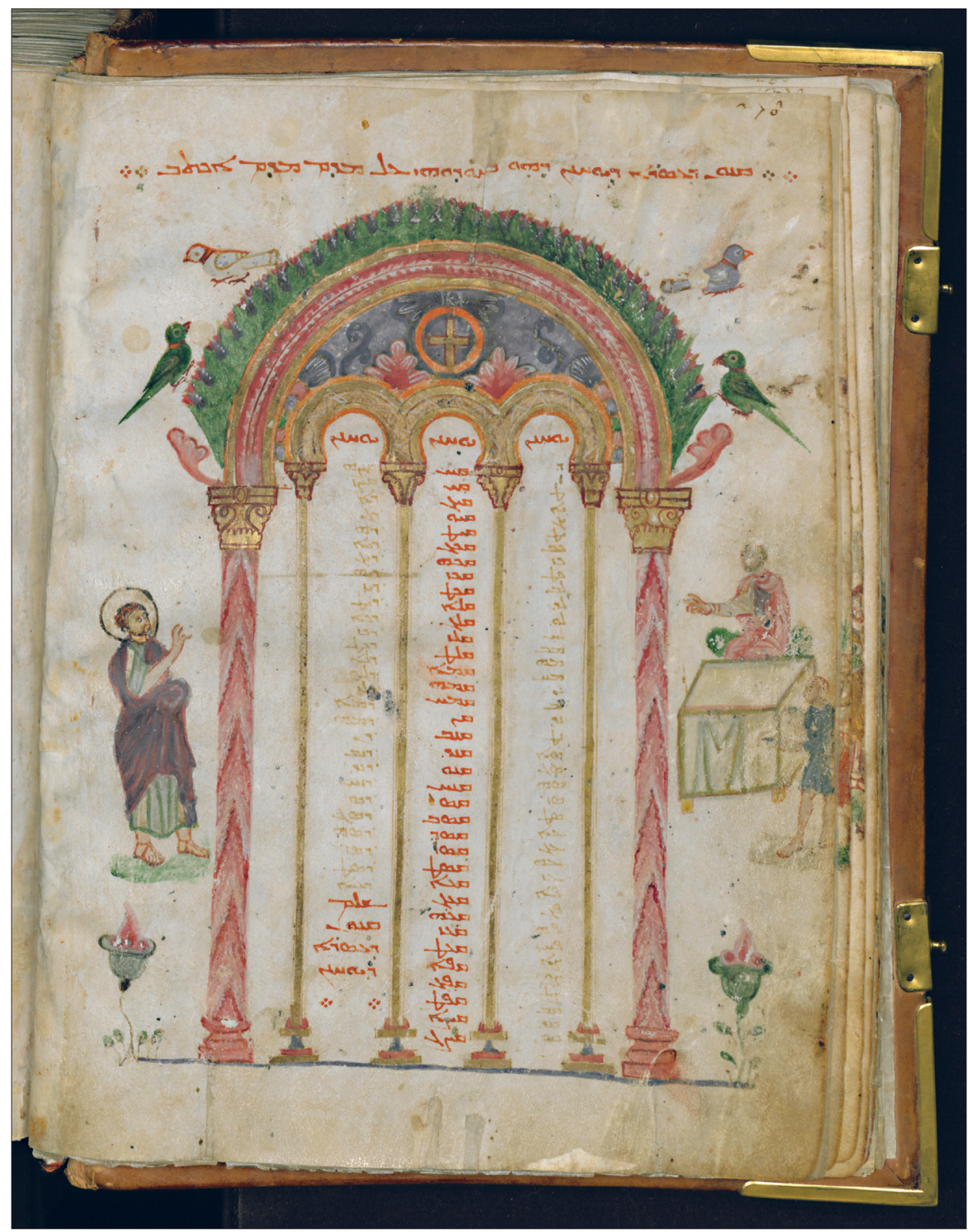

Ill. 12. The Rabbula Gospels (fol. 12v), manuscript, A.D. 486,

Biblioteca Medicea Laurenziana, Florence, ms. Plut. 1.56, f. 12v

(reproduced with permission of MiBACT; further reproduction by any means is prohibited) 
of what is today Greece. ${ }^{41}$ The theme of the trial, presented in two sections was depicted on three leaves, the last of which did not survive. ${ }^{42}$ The entire message focuses on the magnificence of the Roman jurisprudence, showing it through different symbols: a table, Roman standards, a scroll, a throne and the majestic posture of Pilate. Having analysed the illuminations, William C. Loerke concluded that they were modelled on monumental wall paintings from Domus Pilati where the events prior to Pascha had been painted for the sake of pilgrims coming to Jerusalem. ${ }^{43}$ This theory is supported by the composition of the miniature which is closed at the top with a semi-circular blue line, reminiscent of the shape of an apse. There are a lot of written accounts from the beginning of the $4^{\text {th }}$ century, in particular the writings of Cyril of Jerusalem and Egeria, confirming the popularity of this place among pilgrims. ${ }^{44}$ This hypothesis, even though accepted in academic circles, has not been supported with any solid source material and seems difficult to sustain.

The first miniature (fol. 8r) in the top section shows the Roman governor sitting on a raised throne with a rectangular back support in front of a table (ill. 13). Both pieces of furniture are covered by light blue cloth. Thoughtful Pilate sits on a red cushion, his chin resting on a scroll held in right hand. He is presented as a sage, with a grey beard and thinning grey hair. To his left there is a group of five Roman officials with their gaze fixed on Jesus who stands on the other side of Pilate. The governor looks right at Jesus and the two men pressing charges. One of them has raven-black hair. It is Caiaphas who stretches his left hand towards Pilate in a demanding gesture. The other one is Annas, presented as an old man. He does not look at Pilate but at Jesus standing alone behind him at a small distance. The Accused tellingly looks back at Annas. Why? The answer to this question can be searched for in the scene below, where on the right side of it Judas comes to Annas and Caiaphas to return the pieces of silver. Caiaphas seems only to witness the act. Annas turns his head away from the traitorous disciple and raises his arms in protest. Judas leaves. The scene of his suicide is shown on the left part of the bottom section of the illumination. Above the blue

\footnotetext{
that the code is definitely not earlier than the $4^{\text {th }}$ century, and not later than the $6^{\text {th }}$ century.

41 Ibidem, p. 74.

${ }^{42}$ Cf. W.C. Loerke, The Miniatures of the Trial..., p. 175.

43 Ibidem, p. 171.

44 Ibidem, p. 189.
} 


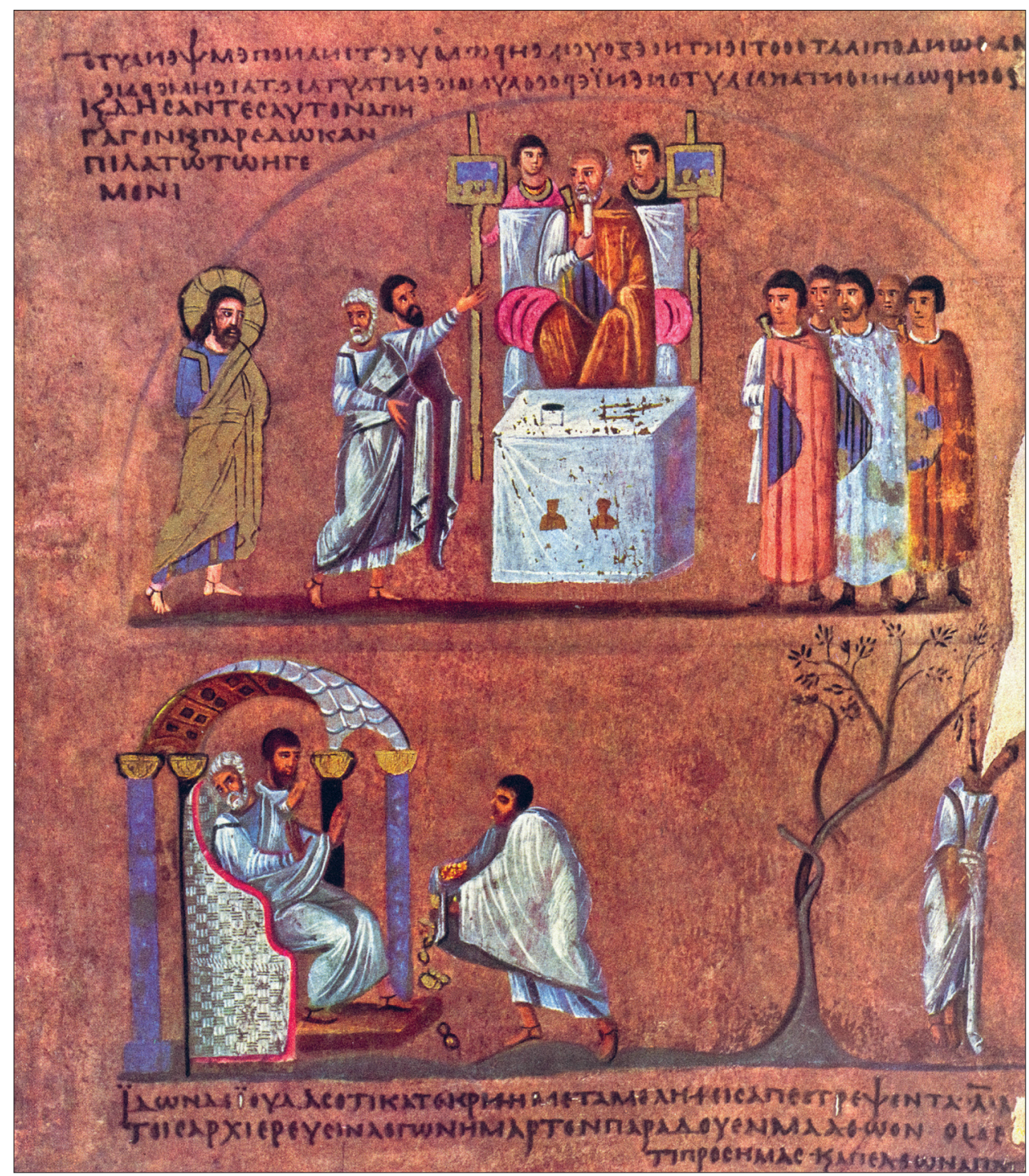

Ill. 13. Jesus before Pilate and Iudas, in: Codex purpureus Rossanensis (fol. 8r), manuscript, $5^{\text {th }}-6^{\text {th }}$ century, Duomo di Rossano (photo author)

line there is a Greek text reading: "And they bound him and led him away and delivered him over to Pilate the governor" (Mt 27,2). The quotation does not correspond to the picture which seems to be a better illustration to the words of Saint John (Jn 19,10-11): “So Pilate said to him, 'You will not speak to me? Do you not know that I have authority to release you and authority to crucify you?' Jesus answered him, 'You would have no authority 
over me at all unless it had been given you from above. Therefore, he who delivered me over to you has the greater $\sin ^{\prime}$." Under the bottom section of the illustration there is an inscription which is a non-verbatim quotation from the Gospel of Matthew (Mt 27,3-5):45 "Then when Judas, his betrayer, saw that Jesus was condemned, he changed his mind and brought back the thirty pieces of silver to the chief priests and the elders, saying 'I have sinned by betraying innocent blood.' They said, 'What is that to us? See to it yourself.' And [...] he went and hanged himself." In this case the text is true to the scene presented.

It seems that the silence of Jesus, his telling look at Annas and astonishment of Pilate are the main theme of this illumination. As William C. Loerke observed, the inscriptions do not correspond to the scene depicted, which is definitely more in accord with the subsequent verses of the Gospel by Matthew $(27,12-14)$ : "Now Jesus stood before the governor, and the governor asked him, 'Are you the King of the Jews?' Jesus said, 'You have said so.' But when he was accused by the chief priests and elders, he gave no answer. Then Pilate said to him, 'Do you not hear how many things they testify against you?' But he gave him no answer, not even to a single charge, so that the governor was greatly amazed."

The other illumination (fol. $8 \mathrm{v}$ ) also shows Pilate enthroned, in front of the table (ill. 14). This time, however, on either side he has a group of people. On the left-hand side there is a group of - presumably - Jews demanding capital punishment. They raise their arms in a gesture indicating demand. Among them we can recognize Annas and Caiaphas standing closest to the tribunal. Below there is Barabbas, strongly leaning forward. His hands, tied up behind his back, are held by a prison guard. The other guard, looking at Pilate, holds a chain attached to Barabbas's neck. He seems to await the final decision. To Pilate's right there is a group of people wearing much simpler and more modest clothes. They protest against an unfair judgement and demand that Jesus be freed; below there is Jesus flanked by two Roman officials. One of them holds two green rods that look like sticks or twigs. In my opinion it is a broken mace, the so-called corylus, the haze twig. Corylus is a symbol of fair judgement. In this case as justice had not been met, the twig is broken. The dress of the Roman officials is in contrast to the clothes worn by the prison guards, whose short tunics look more like rags. William C. Loerke speculates that the two

45 Cf. ibidem, p. 172. 
green rods are a reference to the tree of Jesse. They would denote royal status; the usurpation of which Jesus was accused of. I am of opinion that this interpretation is unconvincing and incompatible with the message of the illumination. ${ }^{46}$

Who are the two Roman soldiers next to Jesus, wearing cloaks with tablions? William C. Loerke determined that one of them is a centurion (Mk 15,44-45), and the other one is Longinus (Jn 19,34), the memory of whom had been retained in early Christian tradition. Indeed, Longinus is often depicted in crucifixion scenes - in early manuscripts (the Rabbula Gospels), and on plates (the binding of the Echternach Gospels). ${ }^{47}$

Above the blue line closing the composition there is a quotation in Greek from the Gospel of Luke: "When he learned that Jesus was under Herod's jurisdiction, he sent him to Herod, who was also in Jerusalem at that time (Lk 23,7)." The inscription does not match the picture. It seems that the author wanted the quotations to complete the illuminations in giving a full account of the trial of Jesus. The hand-washing scene was probably painted on the third leaf, now gone. It seems impossible that a motif so significant for early Christian presentations of the trial of Jesus was omitted. ${ }^{48}$

On both illustrations, right behind Pilate's throne, there are two persons wearing robes fastened under their necks with golden fibula pins. ${ }^{49}$ Each of them holds a golden standard with representations of two busts in gold. Most probably these are the images of Roman emperors. ${ }^{50}$ Similar representations of busts are visible on the table cloth on the table before Pilate. In a symbolic way they refer to the tribunal, reminding us that each judge metes out justice in the name of the emperor. ${ }^{51}$ Pertaining to the functions of consular diptychs, they legitimise the activities of the governor. Also, the rotulus held by Pilate signifies a legal act confirming the office held. The table symbolises judge's competence. All these objects denote a trial which, in fact, takes place before the Roman emperor and - since the reforms introduced by Theodosius I - is typical of an early Byzantium trial. ${ }^{52}$

\footnotetext{
46 Ibidem, pp. 182-183, where the author considers the meaning of green rods.

47 Ibidem. The author refers to Cyril of Jerusalem and Hesychius, the bishop of Alexandria.

48 Ibidem, p. 175.

49 This costume detail was noted by G. Cavallo, Codex Purpureus..., p. 86.

50 Ibidem, p. 87.

51 Cf. W.C. Loerke, The Miniatures of the Trial..., p. 177.

52 Mt 27,19.
} 


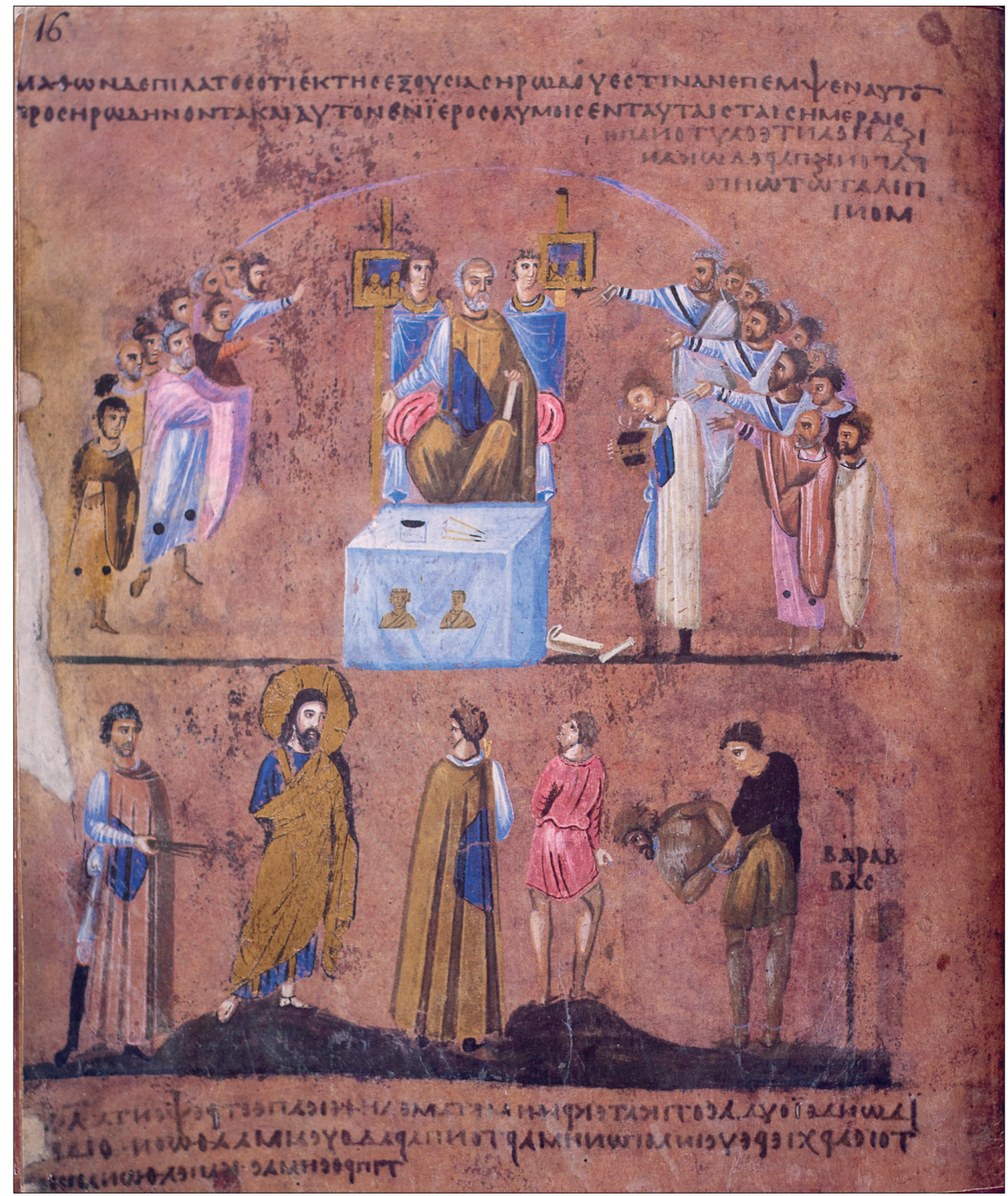

Ill. 14. Jesus before Pilate and Ecce Homo, in: Codex purpureus Rossanensis (fol. 8v), manuscript, $5^{\text {th }}-6^{\text {th }}$ century, Duomo di Rossano

Since in the end of the $6^{\text {th }}$ century the apocryphal Gospel of Nicodemus gained in popularity, the Passion cycles became more and more developed, and the trial of Jesus was presented in several sequences. Until the $9^{\text {th }}$ century, Pilate remains a symbol of justice and law - he wears Roman dress and a tiara on his head. After this period scenes of the trial 
before high priests isolated from the Passion cycles start to appear. Jesus is no longer presented as a young man; he has facial hair, shows signs of suffering, wears a crown of thorns, sometimes he is depicted with his hands bound and held by soldiers. Plates from the times of the Carolingian Empire show all Passion events, not just the trial before Pilate. Vast numbers of ivory plates and manuscripts with miniatures presenting the trial of Jesus confirm the popularity of the subject. Apart from typical presentations, there are scenes with original messages.

Diptych from the Cathedral Museum in Milan ${ }^{53}$ (ill. 15) is an interesting example from the Carolingian Empire. The subject matter is death and Resurrection of Christ. The first scene presented in the top section of the left plate presents Jesus washing Peter's feet surrounded by the disciples. Large basin resembles a baptismal font. Directly underneath, in an arcade, there is Pilate washing hands in a bowl held by a servant. Jesus is shown just above the servant. Both of them lean forward showing a connection between them which seems to be a deliberate act from the artist. References to ritual ablution, baptism and purge from sin are obvious. ${ }^{54}$

Until the beginning of the $9^{\text {th }}$ century, in any artwork, the act of hand-washing refering to baptism, is a compulsory element in scenes depicting the trial of Jesus. One of the few exceptions is an illumination from the Rossano Gospels. The washing of hands symbolised baptism, whereas the table on which the vessels were placed represented the Eucharistic altar. In medieval art the following motifs were also linked to Pilate's hand-washing act: Moses crossing the Red Sea, the miracle in Cana of Galilee, the walking on water and the flow of blood and water from Jesus's side. ${ }^{55}$ All these scenes referred to the sacrament of baptism.

In the artwork of the $9^{\text {th }}$ century, the gesture of hand-washing was no longer predominant, and Pilate was shown with the attributes of law a sceptre or a scroll. At that time extended Passion cycles developed - they included the scenes of flogging, mockery or episodes with Judas. There are also works where Pilate was deprived of his attributes - a pitcher and a basin. It seems that one of the earliest examples of such representation is the illumination in the Utrecht Psalter (ill. 16), produced between

53 The object is stored in the Cathedral Museum in Milan, inventory no. 1386.

54 The act of washing feet has a long biblical tradition. It is a ritual not only of hygienic but also of spiritual purpose. Cf. Gen. 18,4; 24,32.

55 C. Hourihane, Pontius Pilate, Anti-Semitism..., pp. 69 and 73. 


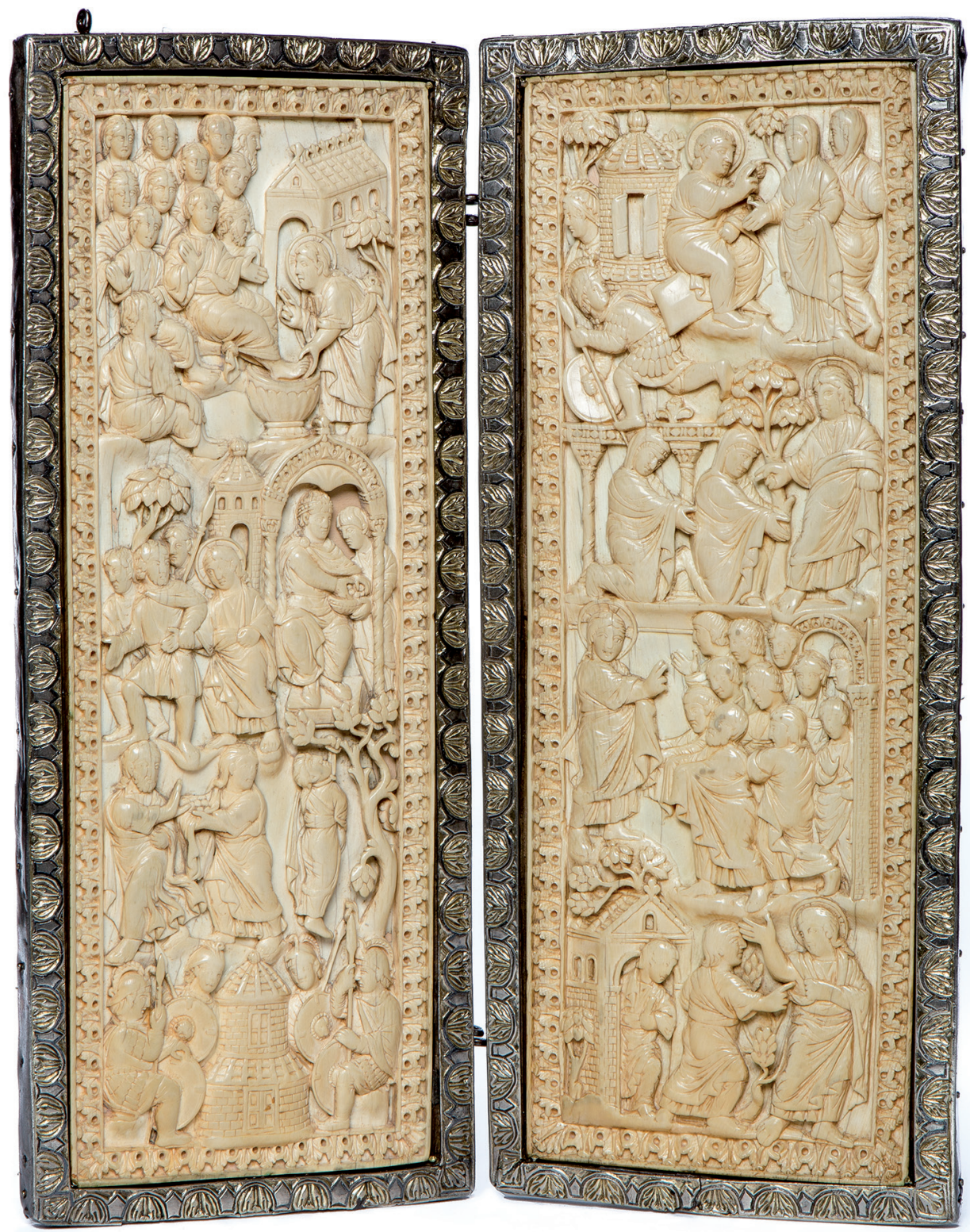

Ill. 15. $9^{\text {th }}$ century ivory diptych with scenes from the Passion, Museo del Duomo, Milan, inv. no. 1386 (photo Veneranda Fabbrica del Duomo di Milano) 


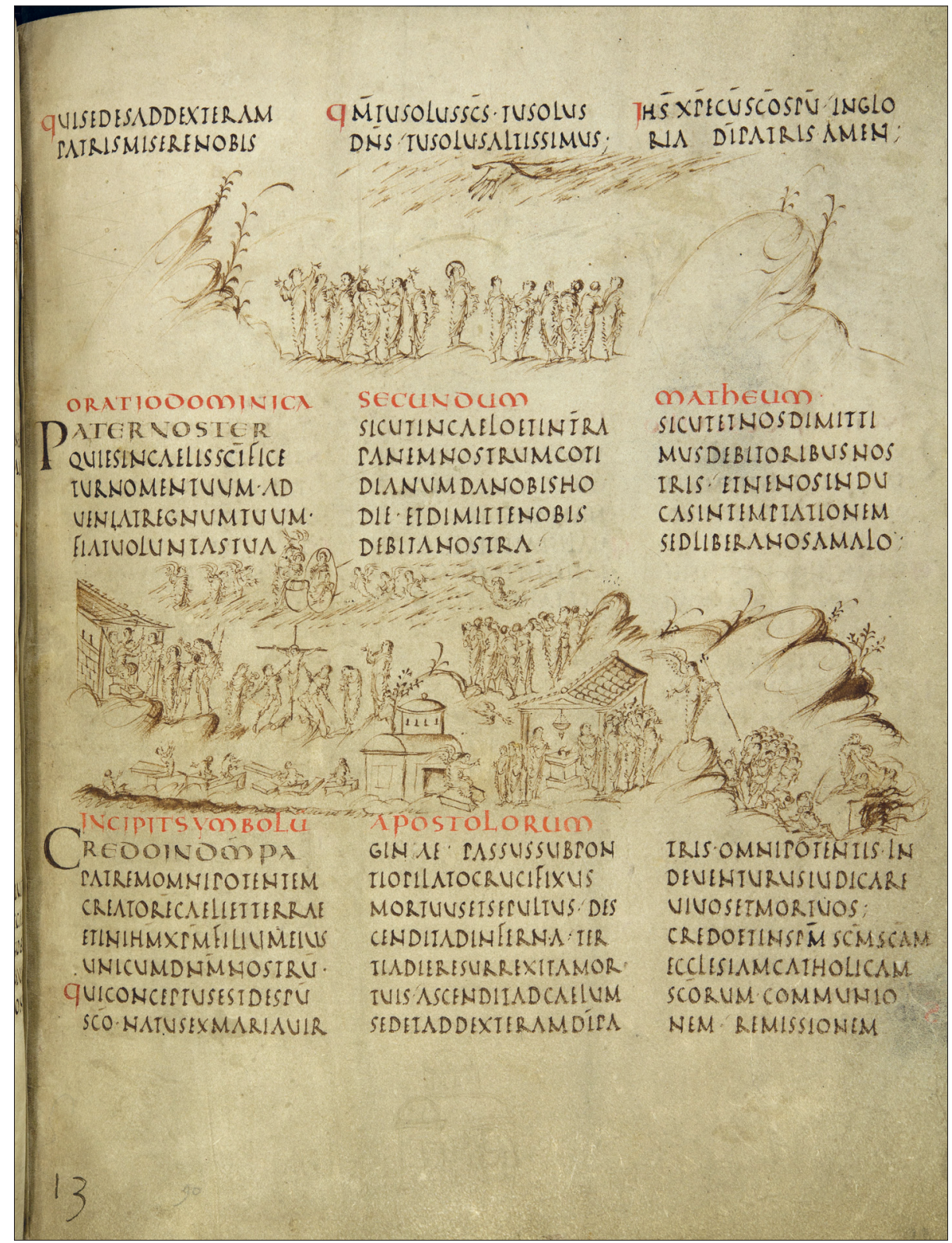

Ill. 16. Symbolum Apostolorum, in: The Utrecht Psalter (fol 90r), manuscript, c. A.D. 830, Universiteit Utrecht, inv. no. Ms 32 
the years 816 and $835 .^{56}$ The artist, representing the school of Reims, showed the governor sitting in the praetorium and pointing to tortured Jesus. The governor holds a sceptre - a symbol of imperial power - and his feet are placed on a footrest, which was a right granted to emperors. The act of hand-washing was completely omitted. Nervous and edgy lines emphasise the gravity of the situation. Next to it there is the crucifixion scene.

An interesting painting was produced in the Benedictine Abbey of Saint John in Müstair (ill. 17). In the series of frescoes brilliant in terms of iconography, form and composition, dating from around the year 800, there is a figure of Pilate presented. ${ }^{57}$ Like an emperor, he sits on a cushion placed on a throne, resting his feet on a suppedaneum. His tunic is white. His hands are turned to the right, held over a basin where a servant pours water on them. Pilate ignores it and looks straight ahead, as if directly at the viewer. His head is slightly tilted. Behind him there is, only partially preserved, the following scene: Jesus, wearing a white tunic and a coat clasped on the shoulder walks away to the left. The Saviour's head is surrounded by the cruciform halo. To his right there is a mysterious figure in Roman dress who touches Jesus's arm with his right hand, as if handing over the condemned man. This figure is strikingly similar to Pilate, therefore I deem it to be a simultaneous scene, presenting the handing of Jesus over to the Jews. The left-hand side fragment of the painting has not survived, I believe however that it would have presented the Jews. ${ }^{58}$

The fresco with Pilate in it is preceded by the scene called by researchers Jesus before the High Council (ill. 18). It has survived only partially; it presents two figures seated on a throne on which there lays a cushion. The first figure wears a dark tunic; probably behind him there was a group of people of which only one figure and numerous gesticulating hands survived. All these people surround a figure in dark tunic who most probably represents Caiaphas. Next to him sits another man, wearing a white tunic. According to researchers it is Annas, but it is difficult to agree with such an

56 Ibidem, p. 95.

57 M. Wolf, Müstair. Falttafeln zu den Mittelalterlichen Wandbildern in der Klosterkirche / Piante pieghevoli delle pitture parietali medievali nella chiesa dell'abbazia, München 2007, p. 8. The detailed arrangement of frescoes is presented on a sheet attached to the publication.

58 The literature of the subject does not provide an in-depth interpretation of this painting; most often it contains a description of Pilate and Jesus. Cf. J. Goll, M. Exner, S. Hirsch, Müstair. Die mittelalterlichen Wandbilder in der Klosterkirche. UNESCO-Welterbe, München 2007, p. 167. See there for further bibliography. 


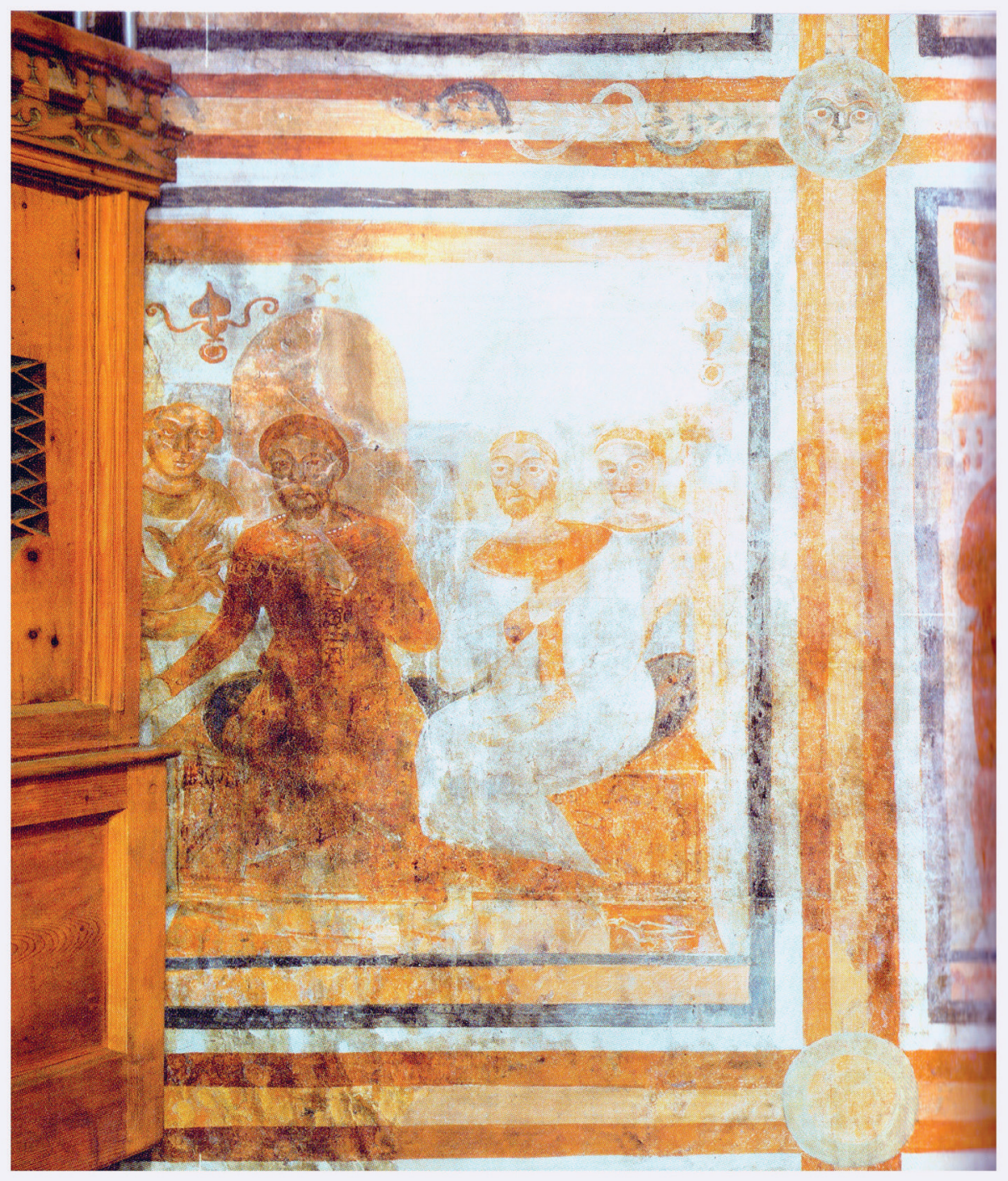

Ill. 17. Pilate washing his hands, fresco, c. A.D. 800, Benedictine Convent of St. John in Müstair (photo author)

interpretation. ${ }^{59}$ The complexion of this other man is fairer than Caiaphas's and the look soft. His right hand touches his chest where the heart is, left hand rests on his knees. Behind him stands a figure in a white tunic, most probably holding a sword. I suppose that this is Pilate and his servant. It is

59 Ibidem, p. 166. 
difficult to imagine Annas with his hand to his heart, especially that this is the pose of Pilate in the adjacent painting, described above. The figure of Jesus is not visible, it is possible that it had never been present, and that the scene presents the meeting of the Sanhedrin which - according to apocrypha - Pilate also attended.

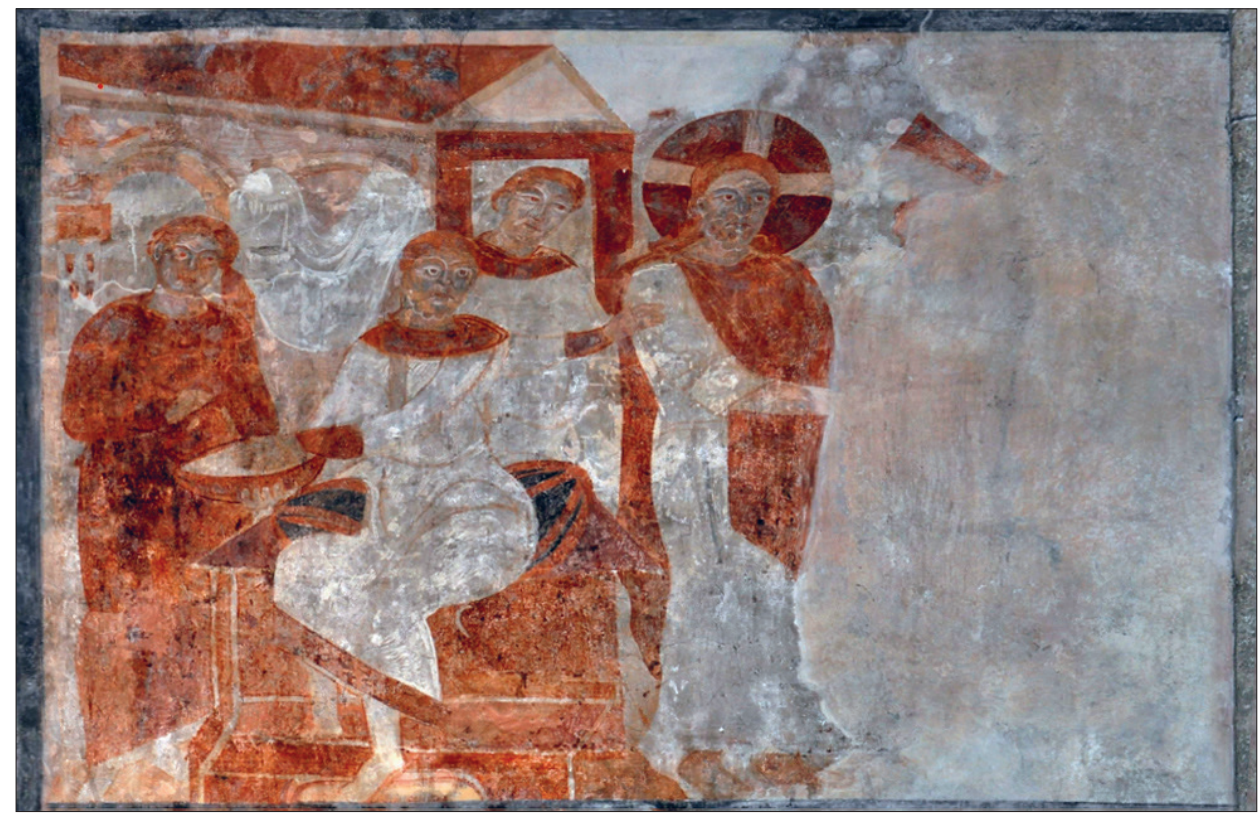

Ill. 18. Jesus before Sanhedrin, fresco, c. A.D. 800, Benedictine Convent of St. John in Müstair (photo author)

On the plate donated by Otto I to the cathedral in Magdeburg, Pilate washes his hands whilst looking at Jesus and witnessing his flogging. The plate was produced between the years $962-973$ and is currently housed in a museum in Munich (ill. 19). Its author is unknown, he was probably from an Italian workshop or from Reichenau. ${ }^{60}$ The message of the artwork is quite original: Pilate is not responsible for Jesus's death as he only sentenced him to flogging. He was forced to pass a death sentence; therefore, he washes his hands trying to distance himself from the consequences of an unfair verdict. The scene takes place in the praetorium. Pilate is seated on

60 Bayerisches Nationalmuseum München, inv. no. 17/418-420; C. Hourihane, Pontius Pilate, Anti-Semitism..., p. 92. 
a throne with a cushion, similar to an emperor's throne. His feet are placed on a footrest. A servant is to his left, washing his master's hands. The governor ignores this activity, looks right, directly at Jesus tied to the column supporting the roof of the praetorium. The eyes of the sentenced and the judge meet. The source of this scene should be searched for in apocrypha which mention Pilate's participation in subsequent stages of Jesus's Passion. The plate reveals the artist's fondness for details - there are draped curtains in the room and lush vegetation outside.

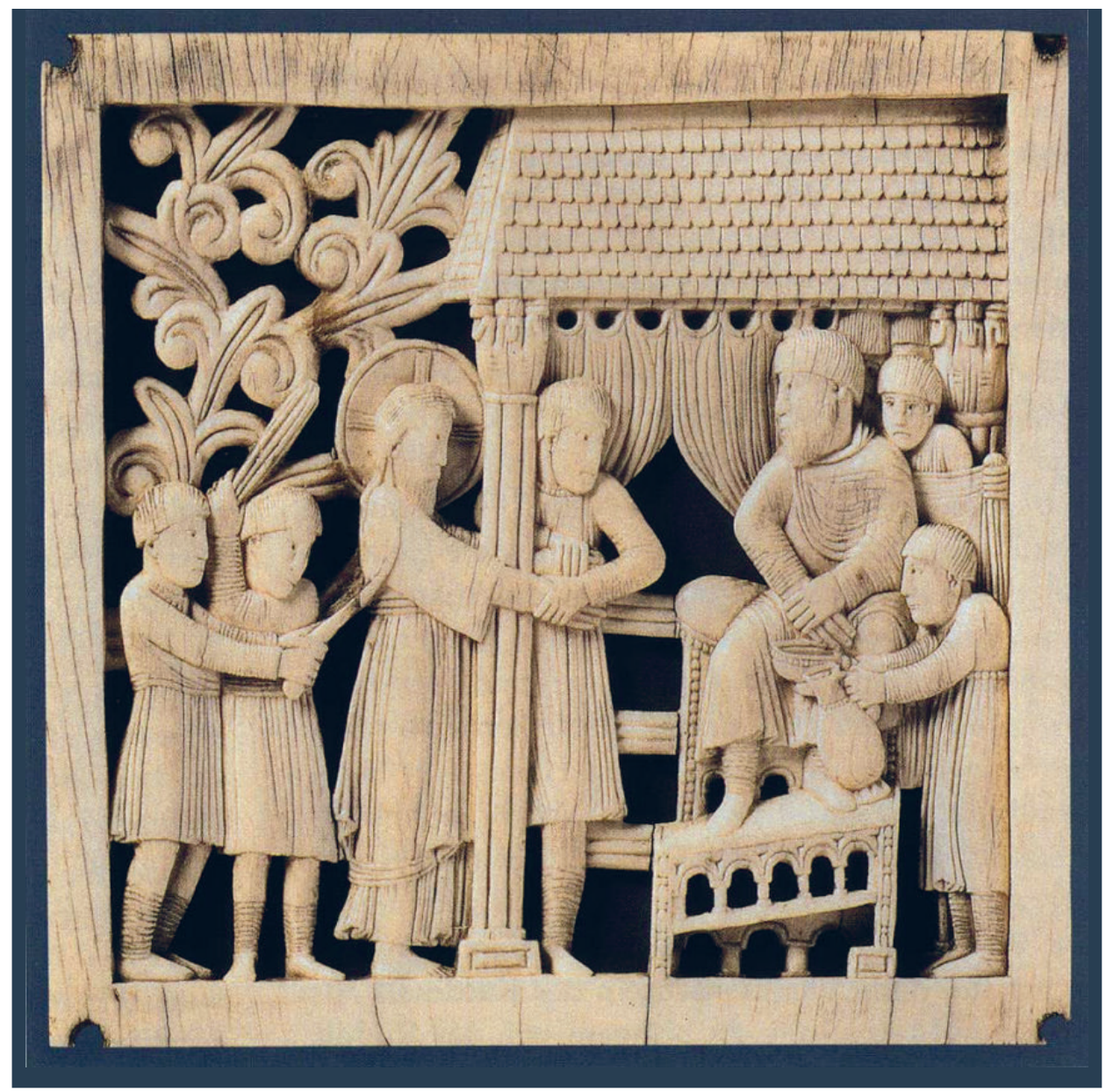

Ill. 19. Flagellation and Christ before Pilate, ivory, between A.D. 962 and A.D. 973,

Bayerisches Nationalmuseum München, inv. no. 17/418-420 
One of the last positive images of Pilate presented as a fair judge can be found in the Codex Egberti produced between the years 977 and 993 in Trier or Reichenau. ${ }^{61}$ A full-page illumination on leaf $80 \mathrm{v}$ was divided into three sections (ill. 20) and is a typical narrative picture. In the top section there is Jesus escorted by a cohort to stand before Annas. Enthroned high priest tears apart a green cloth. He is depicted according to contemporary practices of presenting Jews: he has a black beard and black hair. He looks straight at Jesus who wears a long tunic, his head surrounded by a cruciform halo. The middle section shows the scene of the denial of Saint Peter and the bottom one - the flogging of Jesus where Pilate, deprived of any attributes, stands next to the lashed Saviour. It is one of the earliest representations of Pilate as a witness to flogging. ${ }^{62}$ He can be identified thanks to an inscription reading PILATVS placed at the head level. The governor is shown as a ruler who is only responsible for the ordering of the flogging. The narrative continues on the next miniature, very stern and simple in its message, showing only two figures: Jesus and Pilate standing in front of the praetorium (fol. $82 \mathrm{v}$ ). Both figures are signed, both raise right hands. Their delicate movement and gestures indicate that they are in the course of a conversation. The next illumination (fol. $82 \mathrm{r}$ ) depicts an Ecce Homo scene (ill. 21), extraordinary in the $10^{\text {th }}$ century. Pilate stands next to Jesus, holding his hand and with the right hand he points to the Saviour. Paying tribute to Jesus, Pilate looks at a group of people before him. Some of them kneel, others stand. These are Jewish priests (pontifices) and soldiers (milites). Pilate is shown here as believing in Jesus's innocence. He does not hold any attributes of power and resembles a common man. ${ }^{63}$ None of the miniatures in the Codex Egberti shows the governor enthroned. Annas is the ruler - he is seated on the throne and his feet rest on a stool.

In the $10^{\text {th }}$ and $11^{\text {th }}$ century, the ewer and the bowl were no longer essential elements in the scenes presenting the trial of Jesus. The gesture of hand-washing returned to the iconography of this subject in the $12^{\text {th }}$ century. Allusions to baptism used to be common, however in later centuries they waned. ${ }^{64}$

${ }_{61}$ Trier, Stadtbibliothek, inv. no. 24, fol. 80v, 82r, 82v.

62 Cf. C. Hourihane, Pontius Pilate, Anti-Semitism..., p. 98.

63 A similar scene is painted in the Pericopes of Henry III from mid- $11^{\text {th }}$ century, Bremen, Stadtbibliothek, inv. no. b.21, fol. 53v. Cf. C. Hourihane, Pontius Pilate, Anti-Semitism..., p. 101.

64 Ibidem, p. 95. 


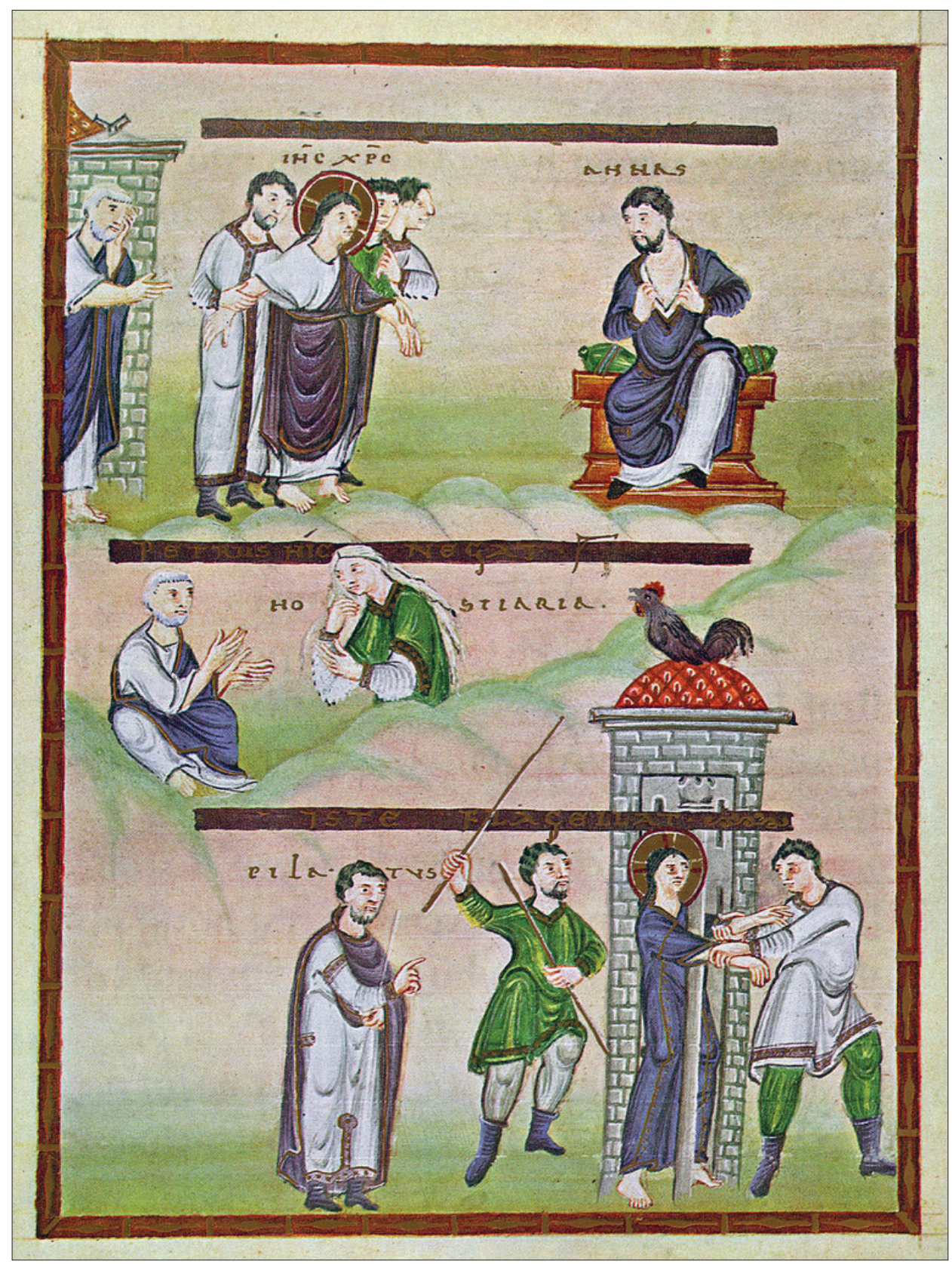

Ill. 20. Codex Egberti (fol. 80v), manuscript, A.D. 977-993,

Stadtbibliothek, Trier, inv. no. 24

(photo Stadtbibliothek Weberbach, Trier) 


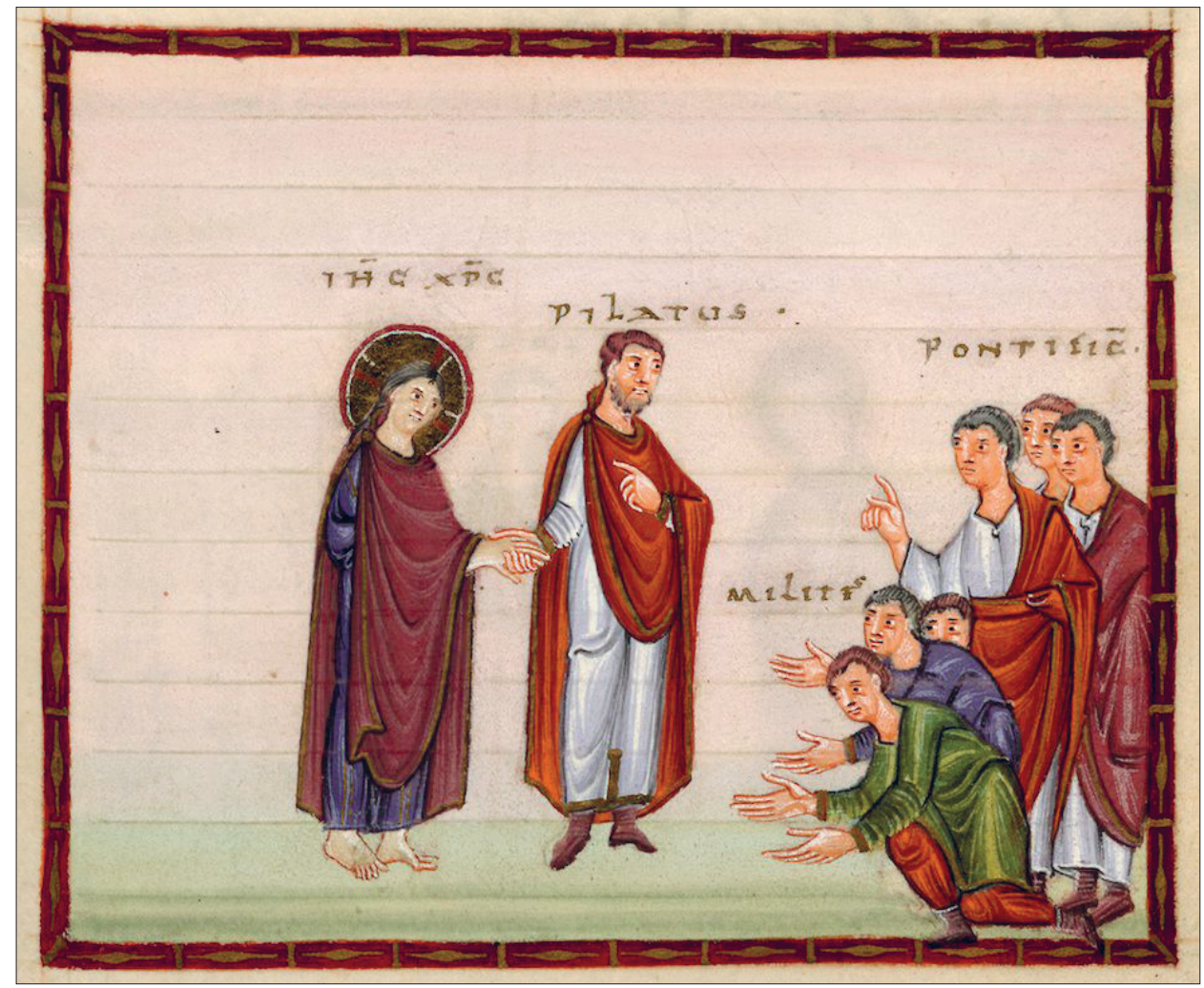

Ill. 21. Ecce Homo, in: Codex Egberti (fol. 82r), manuscript, between A.D. 977 and A.D. 993, Stadtbibliothek, Trier, inv. no. 24 (photo Stadtbibliothek Weberbach, Trier)

Based on the iconography analysed above, we can see that certain elements are recurrent. They include a curule seat, crossed legs of the judge, a laurel wreath, a table, presence of other persons wearing soldiers' uniforms and clerks whose role was probably that of a record taker. The image of Pilate in Late Antiquity is, in fact, a representation of early court scenes. 


\section{Bibliography}

The Apologies of Justin Martyr, transl. A. Roberts, J. Donaldson, with brief notes and prefaces A. Cleveland Coxe, Greenwood 2012.

Bourguet P. du, Early Christian Art, transl. Th. Burton, New York 1971.

Brown Tkacz C., Susanna as a Type of Christ, Studies in Iconography 1999, vol. 20.

Cavallo G., Codex Purpureus Rossanensis, Roma 1992.

Coburn Soper A., The Latin Style on Christian Sarcophagi of the Fourth Century, The Art Bulletin 1937, vol. 19, no. 2.

Crossan J.D., Who Killed Jesus? Exposing the Roots of Anti-Semitism in the Gospel Story of the Death of Jesus, San Francisco 1995.

Filarska B., Początki sztuki chrześcijańskiej, Lublin 1986.

Foletti I., The British Museum Casket with Scenes of the Passion: The Easter Liturgy and the Apse of St. John Lateran in Rome, in: The Fifth Century in Rome: Art, Liturgy, Patronage, ed. I. Foletti, M. Gianandrea, Rome 2017.

Goll J., M. Exner, S. Hirsch, Müstair. Die mittelalterlichen Wandbilder in der Klosterkirche. UNESCO-Welterbe, München 2007.

Hourihane C., Pontius Pilate, Anti-Semitism, and the Passion in Medieval Art, Princeton 2009.

Jan Chryzostom Św., Homilie na Ewangelię wedtug św. Mateusza. Część druga: homilie 41-90, ed. A. Baron, transl. A. Baron, J. Krystyniacki, Kraków 2001.

Jońca M., Czyste ręce prefekta Judei, Palestra 2016, vol. 61, no. 3.

Jońca M., Głośne rzymskie procesy karne, Wrocław 2009.

Kobielus S., Concordia Novi et Veteris Testamenti. Zapowiedzi dzieła odkupienia i jego spetnienie w teologii i sztuce średniowiecza, Poznań 2013.

Kobielus S., Ikonografia zdrady i śmierci Judasza. Starożytność chrześcijańska i średniowiecze, Ząbki 2005.

Kuryłowicz M., Prawa antyczne. Wykłady z historii najstarszych praw świata, Lublin 2006.

Lisicki P., Kto zabit Jezusa? Prawda i interpretacje, Kraków 2013.

Loerke W.C., The Miniatures of the Trial in the Rossano Gospel, The Art Bulletin 1961, vol. 43, no. 3 .

Rupiewicz R., Sąd nad Jezusem. Studium ikonografii oraz źródeł od chrześcijańskiego antyku do nowożytności, Warszawa 2018.

Sobczyk M., Proces Jezusa oczami historyka i prawnika, Studia Iuridica Toruniensia 2013, vol. 12.

Spier J., Picturing the Bible. The Earliest Christian Art, New Haven-London 2008.

Święcicka P., Proces Jezusa w świetle prawa rzymskiego. Studium prawno-historyczne, Warszawa 2012.

Tertulian Q.S.F., Apologetyk, transl. J. Sajdak, Poznań 1947. 
Wolf M., Müstair. Falttafeln zu den Mittelalterlichen Wandbildern in der Klosterkirche / Piante pieghevoli delle pitture parietali medievali nella chiesa dell'abbazia, München 2007.

\section{List of Illustrations}

1. Jesus. The Sarcophagus of Junius Bassus - detail, marble, A.D. 359, Museo Storico del Tesoro della Basilica di San Pietro (photo J. Barańska)

2. Pilate. The Sarcophagus of Junius Bassus - detail, marble, A.D. 359, Museo Storico del Tesoro della Basilica di San Pietro (photo J. Barańska)

3. The Brescia Cascet, end of the $4^{\text {th }}$ century, Museo di Santa Giulia, Brescia, http://www.turismobrescia.it/it/punto-d-interesse/lipsanoteca-360-370-d-c

4. Christ before Pilate, mosaic, $6^{\text {th }}$ century, Sant' Apollinare Nouvo Ravenna (photo P. Kęska)

5. The Brescia Cascet - detail, end of the $4^{\text {th }}$ century, Museo di Santa Giulia, Brescia

6. Sarcophagus of the "Two Brothers", marble, c. A.D. 325-350, Museo Pio Cristiano, Rome (photo J. Barańska)

7. Sarcophagus with scenes from the Passion of Christ, c. A.D. 350, Musei Vaticani, inv. no. 31525 (photo J. Barańska)

8. Sarcophagus with scenes from the Passion of Christ - detail, c. A.D. 350, Musei Vaticani, inv. no. 31525 (photo J. Barańska)

9. Sarcophagus depicting the law delivered to Saint Peter, end of the $4^{\text {th }}$ century, Musée Departemental Arles Antique, FAN.92.00.2487 (photo author)

10. The doors on the exterior of Santa Sabina - detail, the beginning of the $5^{\text {th }}$ century, Santa Sabina, Rome (photo author)

11. Casket - one of four panels, ivory, carved in relief with the Judgement and Denial of St. Pete, c. 420-430, The British Museum, inv. no. 1856,0623.4, https:/ / www.britishmuseum.org/research/collection_online/collection_object_details.aspx?objectId=60925\&partId=1

12. The Rabbula Gospels (fol. 12v), manuscript, A.D. 486, Biblioteca Medicea Laurenziana, Florence, ms. Plut. 1.56, f. 12v (reproduced with permission of MiBACT; further reproduction by any means is prohibited)

13. Jesus before Pilate and Iudas, in: Codex purpureus Rossanensis (fol. 8r), manuscript, $5^{\text {th }}-6^{\text {th }}$ century, Duomo di Rossano (photo author)

14. Jesus before Pilate and Ecce Homo, in: Codex purpureus Rossanensis (fol. 8v), manuscript, $5^{\text {th }}-6^{\text {th }}$ century, Duomo di Rossano, http:/ / www.thehistoryblog.com/ archives/ date/2016/06/page/2 
15. $9^{\text {th }}$ century ivory diptych with scenes from the Passion, Museo del Duomo, Milan, inv. no. 1386 (photo Veneranda Fabbrica del Duomo di Milano)

16. Symbolum Apostolorum, in: The Utrecht Psalter (fol 90r), manuscript, c. A.D. 830, Universiteit Utrecht, inv. no. Ms 32, http:/ / psalter.library.uu.nl/ page? $\mathrm{p}=186 \& \mathrm{res}=1 \& \mathrm{x}=0 \& \mathrm{y}=0$

17. Pilate washing his hands, fresco, c. A.D. 800, Benedictine Convent of St. John in Müstair (photo author)

18. Jesus before Sanhedrin, fresco, c. A.D. 800, Benedictine Convent of St. John in Müstair (photo author)

19. Flagellation and Christ before Pilate, ivory, between A.D. 962 and A.D. 973, Bayerisches Nationalmuseum München, inv. no. 17/418-420, http://earlymedieval.archeurope.info/index.php?page=magdeburg-ivories-flagellation-and-christ-before-pilate

20. Codex Egberti (fol. 80v), manuscript, A.D. 977-993, Stadtbibliothek, Trier, inv. no. 24 (photo Stadtbibliothek Weberbach, Trier)

21. Ecce Homo, in: Codex Egberti (fol. 82r), manuscript, between A.D. 977 and A.D. 993, Stadtbibliothek, Trier, inv. no. 24 (photo Stadtbibliothek Weberbach, Trier)

\section{Sum mary}

The image of a judge in Late Antiquity is shrouded in mystery as visual artefacts depicting court proceedings are scarce. Early Christian sarcophagi and miniatures adorning early manuscripts help in researching this topic. Illustrations of the trial of Jesus found there fully represent jurisprudence of the $4^{\text {th }}$ and $5^{\text {th }}$ century. Western artists had no knowledge of the hearing held at the beginning of the first century in Jerusalem, in a Roman province, hence they recreated what they knew from experience. The pictures presenting the trial of Jesus are probably the most important iconographic evidence of court proceedings in which a judge and an accused stand facing each other.

Based on the iconography analysed, we can see that certain elements are recurrent. They include a curule seat, crossed legs of the judge, a laurel wreath, a table, presence of other persons wearing soldiers' uniforms and clerks, whose role was probably that of a record taker. The image of Pilate in Late Antiquity is, in fact, a representation of early court scenes.

Key words: Pontius Pilate, iconography - law, Early Christian art, Carolingian art, Ottonian art, sarcophagi, plaques 


\section{PONCJUSZ PIŁAT JAKO PÓŹNO ANTYCZNY \\ I WCZESNOŚREDNIOWIECZNY SĘDZIA - ŚWIADECTWA IKONOGRAFICZNE}

\section{Streszczenie}

Wizerunek późno antycznego sędziego pozostaje owiany tajemnicą, ponieważ wizualne artefakty obrazujące procesy sądowe należą do rzadkości. Zabytkami pomagającymi rozpoznać ten temat są sarkofagi wczesnochrześcijańskie oraz iluminacje zawarte we wczesnych manuskryptach. Znajdujące się tam przedstawienia sądu nad Jezusem w pełni odwołują się do kultury prawnej IV i V w. Zachodni twórcy nie mieli wiedzy na temat procesu, który odbył się na początku I w. w Jerozolimie, prowincji rzymskiej. $Z$ tego powodu przedstawiali to, co znali z doświadczenia. Obrazy Sądu nad Jezusem są prawdopodobnie najważniejszymi świadectwami ikonograficznymi przywołującym wydarzenia prawne, w których sędzia i oskarżony stoją naprzeciw siebie.

Na podstawie przeanalizowanej ikonografii możemy zauważyć, że pewne elementy powtarzają się. Należą do nich krzesło kurulne, skrzyżowane nogi sędziego, wieniec laurowy, stół, obecność innych osób w strojach żołnierskich, a także urzędników, którzy być może pełnili funkcje protokolantów. Późno antyczne wyobrażenia Piłata są w istocie odwzorowaniem wczesnych scen sądowych.

Słowa kluczowe: Poncjusz Piłat, ikonografia - prawo, sztuka wczesnochrześcijańska, sztuka karolińska, sztuka ottońska, sarkofagi, plakiety

\section{ПОНТИЙ ПИЛАТ КАК ПОЗДНЕАНТИЧНЫЙ И РАННЕСРЕДНЕВЕКОВЫЙ СУДЬЯ - ИКОНОГРАФИЧЕСКИЕ СВИДЕТЕЛЬСТВА}

\section{Резюме}

Образ позднеантичного судьи остается окутанным тайной, потому что визуальные артефакты, изображающие судебные процессы, редки. Памятниками, которые помогают исследовать эту тему, являются раннехристианские саркофаги и иллюминации, содержащиеся в ранних рукописях. Найденные там изображения суда над Иисусом полностью ссылаются на правовую культуру IV и V веков. Западные художники не обладали знаниями о процессе, который произошел в начале первого века в Иерусалиме, римской провинции. По этой причине они представляли то, что они знали из опыта. Изображения Суда над Иисусом, вероятно, являются наиболее важными иконографическими свидетельствами юридических событий, в которых судья и обвиняемый стоят напротив друг друга. 
Исходя из проанализированной иконографии, мы можем отметить, что некоторые элементы повторяются. К ним относятся курульное кресло, скрещенные ноги судьи, лавровый венок, стол, присутствие других людей в солдатских костюмах, а также должностные лица, которые, возможно, выполняли функции протоколистов. Позднеантичные представления Пилата в сущности являются отображением ранних судебных сцен.

Ключевые слова: Понтий Пилат, иконография - право, раннехристианское искусство, каролингское искусство, оттонское искусство, саркофаги, плакетки 
